\title{
DON QUIJOTE ENTRE SARDUY: PRESENTACIÓN DE LA EMISIÓN RADIAL “CERVANTES ENTRE NOSOTROS”, DE SEVERO SARDUY
}

\author{
Alejandro Fielbaum $S$. \\ Université Paris 8 \\ París, Francia \\ afielbaums@gmail.com
}

\begin{abstract}
El cual autor no pide a los que la leyeren, en premio del inmenso trabajo que le costó inquerir y buscar todos los archivos manchegos por sacarla a luz, sino que le den el mesmo crédito que suelen dar los discretos a los libros de caballerías, que tan validos andan en el mundo, que con esto se tendrá por bien pagado y satisfecho y se animará a sacar y buscar otras, si no tan verdaderas, a lo menos de tanta invención y pasatiempo.
\end{abstract}

(Miguel de Cervantes, Don Quijote 529)

\section{DON QUIJOTE DE LA HABANA}

"Don Quijote fue una sombra que se movía por América", escribe con elocuencia Germán Arciniegas para destacar cuán tempranamente el célebre personaje cervantino comienza a recorrer el continente. El caballero de la triste figura pronto recorre con alegría los distintos espacios del orden colonial, no solo en el formato del libro. Siguiendo su recuento, ese y otros personajes se presentan con sorprendente rapidez en distintos tiempos y espacios americanos:

La primera parte del Quijote se publica en 1605, y en 1607, mucho antes que apareciera la segunda, se presenta en los carnavales de Lima una comparsa con un limeño en traje de Don Quijote. Todo el mundo en la plaza sabía quien era Don Quijote. En 1621 salen 
por las calles de México gentes disfrazadas que representan a Don Quijote, a Sancho, a Dulcinea. En las comparsas figuraban con ellos los héroes fantásticos de las novelas de caballería. Cuando Cervantes pensó en irse a América, sabía hacia dónde le tentaba dirigir sus pasos (Arciniegas 16).

La temprana lectura de Don Quijote 1 puede abrir una clave de lectura poco explorada de las relaciones entre las prácticas letradas y festivas en el continente y también sobre su relación con la metrópolis. Antes que en España, como bien recuerda Leonard (301), los personajes de la novela aparecen en las fiestas americanas, cuando no en textos que abren un nuevo tipo de fiesta, mediante recreaciones que se prolongan en futuros carnavales, cuentos, novelas, dramas, emisiones televisivas, películas y cuanto género pueda existir. De Montalvo a Chespirito, de Fuentes a Cantinflas, de Alberdi a 31 Minutos, por recordar solo algunos ejemplos, los episodios del caballero andante se prolongan y reescriben una y otra vez en Latinoamérica.

En Cuba, tales recreaciones datan del siglo XVIII (Baujín XXV). Las posteriores tentativas de independencia política ponen al personaje en los recorridos de los intelectuales más comprometidos con ella. En el siglo XIX, la lectura de Don Quijote gana importancia en figuras letradas de la talla de José Enrique Varona y José Martí (cfr. Rodríguez).

En efecto, Martí alude directa o indirectamente al personaje cervantino en variados momentos de su obra, de acuerdo al rastreo realizado por González. El más conocido de esos pasajes presenta a Cervantes como amigo del hombre (Martí V, 120). En tiempos aciagos para la libertad y el decoro, apunta Martí, el prosista español prefiere la dulce tristeza del genio y el deleite de las letras.

Martí explica que es en ese repliegue que Cervantes inventa a su personaje. Después de la derrota, se vuelca en cierta ficción de una amistad no funesta. Con ella, parece advertir a los hombres de los riesgos de cualquier quijotismo. Así, en su comentario de Bouvard y Pécuchet, Martí describe a los personajes de tal novela de Flaubert como quijotescos:

No representan hombres, representan al hombre, posiblemente al burgués Don Quijote. El héroe de la Mancha cruzó los desolados llanos

\footnotetext{
De aquí en adelante, marcamos con cursiva cuando referimos al título de alguna de las dos partes de la novela de Cervantes y sin cursiva cuando aludimos al personaje.
} 
con la lanza bajo el brazo, el yelmo sobre la cabeza, y la mano con guantelete, en busca de injusticias para remediarlas; de viudas para defenderlas; y de desventurados para ayudarlos. Bouvard y Pécuchet pasan por la vida del siglo XIX, y nada parecida a un llano, buscando aquel reposo del alma, aquella felicidad que no puede existir en las grandes ciudades. iAy! ¡La felicidad no es fruto del tiempo ! Vuelven lastimados y heridos, y mueren como el Quijote" (XV, 212).

El contraste entre los personajes de Cervantes y los de Flaubert brinda a Martí una imagen del ascenso y decadencia de la burguesía europea. En esas ciudades modernas que retrata en sus crónicas ya no hay tiempo ni espacio para el Quijote, pero aún se puede luchar porque se abra el tiempo de una lectura de Don Quijote con la cual imaginar una nueva forma de lucha. El ideal quijotesco parece, entonces, pertinente en la época de Cervantes, pero su recreación termina siendo algo cómica. Solo otra forma de vida podría hacer plausible su idealismo, que por entonces contrasta de manera más dura con la realidad del mundo burgués.

De manera singular, Martí parece invertir los modos en los que había sido leída la novela de Cervantes: como una pedagogía cómica en los siglos XVII y XVIII, deseosa de enrostrar y corregir los vicios de la ilusión (cfr. Russell), y como ideal romántico en la primera mitad del XIX, capaz de celebrar los sueños de la libertad contra la realidad mundana (cfr. Close). Para Martí, el Quijote deviene cómico después del romanticismo. Como los personajes de Flaubert, su humor lega menos una pedagogía que cierta crítica del saber europeo, cuya imposición en Nuestra América puede parecer a Martí tan fantasiosa como el saber del Quijote.

\section{DON QUIJOTE DE LA PATRIA}

Futuras señas en la isla prolongan esa posible lectura de Don Quijote como una crítica humorística del saber. En algunos de los más destacados autores de la vanguardia literaria se lo lee en diálogo con otras prácticas artísticas, particularmente las vinculadas al humor. Tanto un joven Carpentier (Obras VIII, 346), en 1928, como Cabrera Infante algunas décadas después (Obras I, 186), leen en Chaplin una nueva figura del personaje del Quijote.

Sin embargo, la lectura de Carpentier cambia una vez que parece plausible una lucha política quijotesca, la que pide más reverencia para con 
el personaje. Algunos años después del texto antes citado, Carpentier escribe que los personajes de Don Quijote no eran cómicos ni trasladables al cine o el teatro (Obras XIV, 189).

Pero es la revolución la que termina por consolidar una lectura seria de la novela, a la que otorga particular centralidad. Don Quijote es el primer libro que publica la nueva imprenta Nacional del Gobierno Revolucionario de Cuba. En 1960, con cien mil ejemplares, la publicación se transforma en símbolo de la revolución (Loeza 706).

Para una revolución rápidamente preocupada de las políticas culturales, resulta entonces crucial la puesta en circulación de la literatura moderna entre los grupos otrora excluidos de la lectura. Carpentier narra la existencia de vendedores ambulantes que ofrecen los pesados volúmenes de "¡El Quijo!”. Al igual que el libro, la escena le parece expresiva de los nuevos ideales. Carpentier destaca la rapidez con la que la novela se inserta en la vida social cubana: kioskos, estaciones de omnibús y sillones de limpiabotas se habitúan a una novela que, por una u otra sombra, se abre paso en la isla:

Y lo más extraordinario de todo está en que "El Quijo" se lee en los autobuses, en los cafés, en las playas recién abiertas al pueblo y que, en estos días de canícula, no parecen bastar para tanta gente como a ellas concurre en alborotosos grupos familiares. En todas partes se lee el Quijote. Y quien, poco acostumbrado a enfrentarse con un texto clásico, lo abandona a poco de pintarse la esmirriada grupa de Rocinante en el campo de Montiel, carga con el tomo y lo lleva a su casa. Donde ya encontrará quien lo abra en mejor oportunidad. Lo importante, lo memorabilísimo, lo memorable, es que por vez primera se haya impreso un Quijote en Cuba, y que ese Quijote, tirado a cien mil ejemplares, haya llevado sus hazañas a la isla entera ("Un nuevo" 553).

La nueva proeza del Quijote parece ser la construcción de un nuevo público letrado, capaz de generar los nuevos saberes que pide la revolución. Según se ha documentado, el gobierno se preocupa por que el libro llegue al campo y a las montañas, con la finalidad de superar el aislamiento también en el acceso a la lectura (Domínguez 99).

Al hacer realidad el ideal de llevar la literatura moderna allí donde su lectura parecía antes imposible, la nueva historia del antiguo libro parece encarnar el ideal de una revolución que se explica con el libro que imprime. El anónimo prólogo de la edición en cuestión, atribuido a Carpentier por 
parte de Baujín y sus coeditores, lee la novela como expresión de la lucha entre lo que el mundo es y lo que se desea.

La ambivalencia que podía leer Martí (y también, por cierto, $\operatorname{Marx}^{2}$ ) en Don Quijote es así minimizada por una lectura que sintoniza con la interpretación romántica del Quijote, cuyos ideales pasan a ser leídos en clave socialista. Los héroes de la revolución toman así la posta quijotesca, al alero de un pueblo que ya no se ríe de ese u otro héroe:

En nuestro país, ahora, podemos sentir los motivos, luchas y trabajos de nuestra gesta nacional, en cierto modo hermanos de la quijotesca quimera. Movido por un hondo ideal el pueblo se ha lanzado a deshacer injusticias sociales, como Don Quijote ponía su corazón y su brazo en la empresa de enderezar entuertos con que ofrendar a Dulcinea, su ideal y su gloria. Como quimera e ideal agónicos se fraguó el heroísmo de nuestra liberación en el ánimo de los hombres de corazón quijotesco, y quijotescas son también, por su pureza, las virtudes que en el pueblo ha revelado y ha hecho renacer la Revolución (XLIV).

No es casual, en esa línea, que las más conocidas figuras de la revolución celebren al protagonista de la novela. En la última carta que escribe a sus padres, Guevara describe su necesidad de partir señalando que siente bajo sus talones el costillar de Rocinante (317), mientras que Castro responde, años después, en una entrevista, que un revolucionario se identifica con el Quijote (88).

La novela es así leída en clave de lucha política por los ideales, en la época de Cervantes y en el presente. Ello permite al gobernante afirmar que, en el siglo XX, el caballero de la triste figura se enfrentaría al imperialismo. En

2 Una nota al pie de El Capital, de hecho, recuerda al caballero de la triste figura para graficar el desfase entre la caballería y el emergente mundo capitalista (100, nota al pie 33). El Quijote aparece así como una figura del desajuste, de cierta impotencia de la conciencia que, por cierto, permite a Marx reírse del quijotismo de sus adversarios en La ideología alemana, donde reescribe (con Engels) las ideas de Stirner mezclándolas con algunos episodios de Don Quijote. Evidentemente, la lectura de ese ejercicio requiere otro trabajo, más aún considerando la posibilidad de leer allí la distancia de Marx ante las lecturas liberales de la novela, como la de Hobbes, así como ante la lectura hegeliana de Cervantes. Simplemente, nos interesa aquí indicar, con Marx, que una lectura marxista de esta y otras novelas puede jugarse más en el análisis de su producción, de la capacidad de una novela de mostrar la producción de las ilusiones sobre la producción, antes que por sus contenidos. 
esta lectura heroica, entonces, el personaje debe prescindir de los momentos en los que la novela puede ser más ambigua, poco heroica. Castro, de hecho, confiesa que los largos relatos intercalados a veces lo aburren (83).

\section{DON QUIJOTE DE LA PAMPA}

La historia del ejemplar impreso por la Revolución cubana muestra la dificultad de mantener esa lectura, tan segura de sus saberes y valores. De acuerdo con una revisión del texto, no solo se suprimen algunas partes de la novela, sino que también se transcriben algunas partes con errores harto graciosos. Por ejemplo, se escribe Quejana y no Quijana, mientras que el capítulo titulado "De lo que sucedió a nuestro caballero cuando salió de la venta" pasa a llamarse "De lo que le sucedió" (Santonja Gómez-Ajero e Isabel Estrada 18). Esos lapsus tan notables permiten imaginar otro tipo de lectura, que ya no puede distinguir tan fácilmente entre queja y gesta, ni puede suponer con tanta claridad dónde sucede tal o cual episodio.

Así, en Lunes de Revolución, Virgilio Piñera celebra la edición de la novela con una aproximación que sobrepasa cualquier lectura heroizante del texto. Junto con destacar el posicionamiento del personaje del lado de los oprimidos, subraya cierta dimensión fantástica que excede cualquier idealismo que crea que pueda guiar la acción histórica con certeza.

De esta manera, Piñera describe al personaje de Cervantes como un Superman de su época. No, por supuesto, porque sea similar la calidad de las obras ni porque compartan su posición política, sino por la relación que abren ante la ficción. En ambos casos, se trata de acciones sobrehumanas que entretienen. Abrir su lectura a los grupos otrora excluidos implica entonces una democratización del placer de la ficción, antes que la transmisión de los valores a través de la pedagogía cómica o del idealismo político.

Según Piñera, en efecto, Don Quijote complica los saberes y distinciones con los que se ejerce uno u otro discurso de la pedagogía y de la política. El escritor afirma que Cervantes monta una fantasmagoría de Don Quijote que no habría sido superada ni por Swift, ni por Poe ni por algún otro novelista posterior. La novela de Cervantes instala así una escritura algo opaca, que ninguna edición podría estabilizar. Antítesis del aburrimiento, Piñera destaca en Don Quijote la imposibilidad de determinar lo que, en uno u otro capítulo, le sucedió: 
Con el Quijote las cosas se complican: los datos de la realidad se tornan irreales - unos molinos de viento se cambian en ejércitos, una venta en castillo, unas monjas son princesas, frailes son cambiados en encantadores y pellejos de vino en gigantes. Esa contingencia, que al principio nos hace morir de risa, termina por dominarnos de tal manera, que no bien llevamos leídos unos capítulos nos sentimos tan quijotescos, tan serios y patéticos que hacemos volar las páginas como esperando que al final de las mismas se nos descubra el misterio que en cada una de ellas el autor se encargó de acumular. Es decir, estamos en presencia de la doble aventura: por un lado se opera con lo conocido -el mundo tal cual lo conocemos; por el otro se parte de lo conocido hacia lo desconocido -lo cotidiano substituido por lo mágico. Entonces si en un libro de aventuras que, por ejemplo, trata de la cacería de elefantes en África nos limitamos al mundo conocido, ocurrirá que en otro libro como el Quijote no solo nos moveremos en ese mundo pero también en el otro, lo que, por simple resultado aritmético, arroja un saldo mayor de apasionada curiosidad (7).

La composición de Don Quijote redobla la ficción al narrar una historia desconocida en lo conocido. Lleva al sujeto más allá de lo que cree conocido, sometiéndolo con fascinación a la inclemencia de una ficción que no se deja administrar. Esta incapacidad de delimitar la ficción aleja la lectura de cualquier humanismo político que quisiera delimitar el sentido de la lectura. La risa pierde su eventual afán pedagógico en una ficción que también dentro de la ficción sutura la distinción entre la realidad y la ficción.

Según Piñera, la novela combina entonces humor y seriedad, mas no porque sus comedias puedan revelar los ideales, sino porque encanta una mirada que se preocupa seriamente por sus comedias. Mirada que solo desea seguir leyendo gracias y no pese a la incapacidad de fijar un saber con el cual reír del personaje, mucho menos de replicar su gesta en alguna isla determinada.

La novela pide, entonces, una lectura hospitalaria con la ficción. En la isla, esta lectura puede hallarse en otros personajes que provienen de otra ficción. A saber, en un diálogo entre los personajes de Paradiso, la célebre novela de José Lezama Lima, cuyo interés por Cervantes, en general, y Don Quijote, en particular, ha sido bien rastreado por Cuiñas. Acaso en continuidad con el discurso de Piñera, Cemí y sus nuevos amigos critican en Paradiso al hispanismo y leen Don Quijote en diálogo con el imaginario orientalista que despliega Lezama Lima. 
La capacidad de la novela de Cervantes de sobrepasar los marcos españoles no se juega en la eventual universalidad de los valores del héroe, sino en su capacidad de abrir el juego ilimitado de la ficción, al punto de que sus personajes pueden ser pensados con otras ficciones. Así, después criticar las lecturas biografistas de la obra que oyen en las lecciones de la Universidad cubana a comienzos de los años treinta, los personajes de Lezama Lima describen al Quijote como un Simbad que carece del ave con la cual volar.

Los jóvenes personajes leen en Don Quijote el deseo de aventuras implausibles, de historias que desajustan la ficción que transcurre, sin algún ideal al cual corresponder. Para celebrar esa apertura a la ficción, elaboran imágenes no menos ficticias, nacidas del encuentro entre otras ficciones. Como un San Antonio sin tentaciones, el Quijote cae ante los ideales que se inventa, lo que le otorga un carácter algo grotesco (Paradiso 240).

Lo notable es que, para Lezama Lima, ese mundo esquivo, de ficciones entre ficciones, parece ser el el que acoge la verdadera acción histórica. Así, poco antes de la revolución, Lezama Lima escribe que la Cuba que describe Martí en sus diarios solo tiene como equivalente la casa de los duques que puede leerse en la segunda parte de la novela cervantina ("La dignidad" 307).

Lo que la ficción enseña a la política no pasa entonces por algunos saberes o valores, sino por la capacidad de aprender a leer ficciones. La política se juega en la capacidad de superar la caída grotesca del idealismo sin recaer en la afirmación cínica del mundo. Después del desengaño, la creación política y la literaria han de asumir la equivocidad de toda imagen para no volver a caer ni estar seguras del vuelo. La política, para Lezama Lima, puede comprenderse como la invención de ese ave que le falta al Quijote, y la ficción, como el recordatorio de su carácter artificioso. (El liberalismo, en esa línea, podría leerse como la ficción de una política que se cree no anudada a la ficción. Un buen ejemplo de ello se encuentra, años después, en el notable discurso que da Guillermo Cabrera Infante al ganar el Premio Cervantes, en el que describe Don Quijote como la "parodia de una alegoría" ("Discurso" párr. 2). En lugar de ver en la novela la pasión lezamiana por engaños y desengaños, la lee como un desengaño que permite pensar la ficción sin la realidad histórica de la que se desvía: "No puedo evitar pensar que si los reaccionarios que ocuparon el lugar de los adelantados le hubieran dado permiso para emigrar a lo que ya se llamaba América, su gran libro hubiera sido escrito no en España, sino en la Nueva España. ¿Qué les parece Don Quijote de las Indias? ¿Qué tal Sancho Pampa? No habría habido molinos, pero habría vientos" (ibid.)). 


\section{UNA AMBIGÜEDAD SEVERA}

A fines de 1959, cruza el Atlántico el joven escritor Severo Sarduy, entusiasta colaborador de Lunes de Revolución, declaradamente influenciado por Lezama Lima y Piñera ("En persona" 250). Con una beca brindada por el nuevo gobierno cubano - del que después se ha de distanciar sin la virulencia de Cabrera Infante- viaja a estudiar la historia de la pintura, lo que no le impide desplazarse hacia otras ciudades europeas. Europa le parecía entonces un gran museo, comenta varios años después (I, 7) ${ }^{3}$.

En una de esas visitas, Sarduy conoce a Jean Wahl en la Capilla Sixtina. Comparten después un café, en el que Sarduy declara de entrada que "la literatura no debe ser transparente", según testimonia Wahl (cfr. González), con quien Sarduy comienza una ininterrumpida relación amorosa.

Esa frase evidencia ya cierta comprensión de la literatura, y por cierto también de la pintura, en la que resuenan posiciones cubanas recién descritas. Con cierta comprensión del barroco, Sarduy defiende la necesidad de la ficción de presentarse con la ambivalencia que celebran ante Don Quijote los autores cubanos que rescata. Según Wahl, en ese entonces Sarduy identifica su posición literaria con las de Lezama Lima y Piñera (1448).

Con la promesa de la ficción abierta por tales autores, Sarduy se "va quedando" en París, como testimonia (I, 13). Con la mediación de Wahl, entra en los círculos intelectuales de los que Wahl forma parte. En particular, Sarduy se interesa por las obras de Roland Barthes y Jacques Lacan, quien por ese entonces funda la colección Champ freudien y luego publica sus Escritos por la editorial Seuil, donde trabaja Wahl, quien por cierto se analiza con Lacan entre 1954 y $1960^{4}$.

Enmarcado por tales escenas, Sarduy prontamente comienza a interesarse por la crítica literaria vinculada con el estructuralismo. Contra cualquier posible

\footnotetext{
De aquí en adelante, citamos las obras de Sarduy desde la Obra Completa indicadas en la bibliografía, salvo cuando se trata de textos no incluidos en ellas.

No está de más recordar, pensando en el documento que buscamos introducir, que Sarduy en París comienza a trabajar en el área de divulgación científica de la radiodifusión hispanohablante en Francia. Lamentablemente, se trata de una faceta poco estudiada, la cual quizá podría abrir nuevas algunos recorridos inesperados para leer su obra -por ejemplo, su fascinación con la discusión cosmológica- y su vida - por ejemplo, la amistad con Carl Sagan que se menciona en uno de los pocos artículos que recuerda este trabajo de Sarduy (Blanchard 85)-.
} 
división de la trayectoria de Sarduy en épocas o continentes, la productividad de su lectura pasa por su capacidad de combinar barroco y estructuralismo. En ese cruce explica la incesante articulación barroca del significante, contra cualquier deseo de lectura simbólica de la literatura latinoamericana, como la entonces vinculada en Francia al boom latinoamericano, bien criticada algunos años después por Antoine Berman.

Contra tales discursos humanistas y también contra las formas de literatura promovidas por los distintas diplomacias culturales, Sarduy monta un discurso crítico de cualquier retórica identitaria. El encuentro de Sarduy con el estructuralismo le permite leer la literatura latinoamericana con otra mirada, menos preocupada por la supuesta expresión de la identidad en los contenidos que por la experimentación en la composición de nuevas formas de literatura. En efecto, distintas investigaciones han explicado la productividad que tiene la lectura y enseñanza de Barthes y Lacan para Sarduy, sobre todo a la hora de leer la cultura y la literatura latinoamericana (cfr. Díaz; Dobry; Gallo).

Lejos de limitarse a la literatura de vanguardia, para Sarduy ya en las primeras obras de la tradición hispánica puede leerse una producción de significantes que desajustan el discurso de la identidad. Particularmente, se interesa por Góngora, sobre quien publica un ensayo en la influyente revista de vanguardia Tel Quel en $1966^{5}$.

Junto con ello, Sarduy publica un menos conocido ensayo en la también influyente revista La Quinzaine littéraire. Allí, aprovecha la publicación de un reciente libro sobre Góngora para explicar el carácter crítico que mantiene la escritura barroca ante la mirada burguesa de la literatura, esa que puede

\footnotetext{
Según se ha informado, con ese y otros trabajos, es Sarduy quien introduce en París la noción de escritura barroca (Villegas 151). La afirmación puede ser algo exagerada, por ejemplo al recordar que ya en 1959 Barthes presentaba cierta definición del barroco como una progresiva contradicción entre unidad y totalidad, un arte cuya extensión no suma sino que multiplica (1247). En ese sentido, quizás sea excesivo pensar que es el encuentro con Sarduy lo que presenta a Barthes el barroco. Lo que parece introducir el cubano es la posibilidad de leer allí cierta forma de ironía, cierto pliegue del texto en medio del infinito despliegue barroco. La lectura que realiza Sarduy de Cervantes puede leerse en esa dirección y también, por cierto, la abierta por Deleuze al leer el barroco como una lógica del pliegue, del infinito repliegue y despliegue (48). En ese sentido, es plausible afirmar que la pregunta por el barroco abre cierto diálogo entre las discusiones latinoamericanas y francesas que habría que indagar más acabadamente, sobre todo si se recuerda la importancia del cine de Ruiz en la relación entre cine y barroco. Nos limitamos aquí a recordar que Buci-Glucksmann refiere allí a cierto cogito barroco (17).
} 
celebrar a uno u otro autor como un genio previo a la escritura en la que se inventa. Sarduy, por el contrario, lee el barroco como una escritura en la que cualquier figura de autor se instala en la gramática de la obra (“Góngora” 12).

Barroca sería entonces toda escritura que destituya la supuesta propiedad de la obra por parte de alguna autoridad. Así, abre otra relación del sujeto en la lengua, la que ya no puede pensarse como una materia dada que podría administrar. El sujeto barroco emerge en la lengua, en los vaivenes de una lengua que se pliega sobre sí una y otra vez, como intentará explicar la ensayística de Sarduy de ahí en adelante.

Más que una etapa delimitada en la historia de la literatura o la pintura, Sarduy destaca esa posición ante el signo como una economía del exceso, resistente a cualquier determinación semántica. Frente a quien viera allí cierta pérdida de la significación, Sarduy asume que esa desestabilización del signo habilita cierta producción en la lengua, una incierta emergencia de una lengua en perpetuo, placentero desplazamiento (II, 1239).

En su decisivo libro sobre el barroco, Sarduy se vale de Lacan para pensar la escritura barroca como un doble trabajo de elisión que se asemeja al delirio, una escritura en la que los signos se refieren a sí mismos, se vacían de cualquier contenido claro. Con ello, desestabiliza cualquier orden del saber, y así cualquier palabra que se quiera soberana: "Barroco que recusa toda instauración, que metaforiza al orden discutido, al dios juzgado, a la ley transgredida. Barroco de la revolución" (1404), termina escribiendo en el ensayo que dedica a Barthes.

\section{DESANCLADO EN PARÍS}

Junto con tales trabajos críticos, Sarduy comienza a desplegar una escritura literaria que pronto gana interés en París. Su novela Gestos es la primera que publica un autor latinoamericano en Seuil (Molloy 184), cuya colección de literatura latinoamericana dirigirá Sarduy más adelante. En la misma casa editorial luego se publica Cobra, que se ha considerado su obra más cercana a las posiciones de Tel Quel (Prieto 270). La novela pronto es traducida al francés por Philippe Sollers, director de tal revista, con colaboración de Sarduy.

Quien conozca la obra en cuestión, así como a los personajes implicados, puede imaginar las dificultades y diversiones que acompañan el ejercicio de traducción de esa obra, que por cierto termina también siendo publicada en 
Seuil. Wahl recuerda que con Julia Kristeva comentaban la incapacidad de comprender lo que Sollers y Sarduy les contaban, respectivamente, sobre la traducción que realizaban (cit. en Gallo 59).

Esa incomprensión está lejos de significar un fracaso de la traducción. Sarduy y Sollers parecen intensificar en la traducción cierta mirada ante la literatura como un excesivo juego de significantes, crítico de cualquier economía clara de la significación. Así la presenta Sollers en Tel Quel, explicando la obra con algunas nociones de Lacan y Kristeva ("La boca" 35-36).

Sollers, en efecto, celebra la mescolanza de culturas y los juegos en la significación que recorren la obra de Sarduy para caracterizarla como una obra que presenta las "enormes posibilidades de la escritura del continente sudamericano", poco después de señalar que solo conoce bien esa obra en la literatura latinoamericana ("Sollers dos" 122).

Ese interés por la escritura de Sarduy no es exclusivo de Sollers. El propio Barthes, en efecto, la rescata como una clave posible -no la única, ciertamentede renovación de la narrativa francesa. La prosa barroca de Sarduy le permite contraponer el tradicional decoro de la literatura francesa, preocupada por la comprensión del fondo, a la libertad del significante obsesionado por las formas, como la desplegada por Sarduy. Esto permite a Barthes celebrar en la prosa de Sarduy cierto placer en la lengua (II, 408), así como una singular forma de alegría en su teatro (III, 699).

La importancia de Sarduy, para Barthes, sobrepasa una posible defensa de la forma en perjuicio del fondo. De manera más radical, Sarduy parece disolver esa diferencia, y con ello toda la economía del buen decir que organiza el canon de la lengua francesa. En ese sentido, para Barthes, el escritor cubano parece ser un heredero de Mallarmé más fiel que la mayoría de la literatura francesa del siglo XX.

La fascinación de Barthes por distintos momentos y facetas de la creación de Sarduy da cuenta de una preocupación prolongada por su obra, irreductible a cualquier consumo momentáneo. De hecho, Barthes se vale de algunas de las posiciones de Sarduy para argumentos cruciales en su trabajo teórico, tales como la posibilidad de establecer una ironía no voltaireana, vinculada al barroco (II, 49), así como de una lengua literaria utópica en el amor a los significantes, de cierto "paraíso de la palabra" (II, 1498)

6 En ese sentido, el interés que puede haber generado el trabajo de Sarduy sobrepasa cualquier consideración de su obra como ejemplo, latinoamericano o no tanto, de conceptos 
La relación entre Sarduy y los pensadores franceses ya mencionados parece entonces establecer distintas idas y vueltas: si estos se valen de Sarduy para pensar el porvenir de la literatura francófona, Sarduy se autoriza con ellos para leer la historia de la literatura escrita en español. Sarduy pone juego esa estrategia al ser invitado a la prestigiosa radio France Culture, con motivo de los 350 años de la muerte de Cervantes. En la emisión radial del 20 de abril de 1966, Sarduy entrevista a Sollers y luego intercala sus comentarios sobre Don Quijote entre las lecturas, realizadas por el célebre actor Michel Bouquet, de traducciones al francés de algunos pasajes de la novela de Cervantes, del ensayo "Magias parciales del Quijote" de Jorge Luis Borges y de la conocida ficción "Pierre Menard, autor del Quijote", firmada también por Borges, de la que se suprimen algunos párrafos.

Si bien las presentaciones con las que Sarduy acompaña esas lecturas no son extensas, nos parece que su lectura puede ayudar a comprender su posición ante Cervantes en particular y ante el barroco en general, así como a continuar la lectura humorística de Don Quijote abierta por Piñera. En ese sentido, los comentarios de Sarduy son de interés para pensar tanto en la obra de Cervantes como en la de Sarduy, y en la recepción de ambas en Francia.

Por ello, antes de pasar a una transcripción traducida de lo presentado por Sarduy en la radio, nos interesa dar otro pliegue y enmarcar las palabras de Sarduy, aunque sea muy brevemente, en torno a los debates sobre Don Quijote entonces desarrollados en Francia, y también en torno a algunas discusiones acerca de Don Quijote y de Borges. Esperamos con ello aclarar la crítica de Sarduy a cualquier deseo de claridad en la literatura.

\section{DON QUIJOTE DE LA FRANCIA}

En su fascinante libro sobre la perdida versión de la historia de Cardenio escrita por Shakespeare, Roger Chartier subraya el rápido interés que la novela de Cervantes genera en Francia. En las primeras décadas del siglo XVII, no solo se traducen algunas partes o la novela completa, sino que además se presentan distintas versiones teatrales de las historias de algunos personajes,

ya forjados, como lo dejan entrever las despectivas caracterizaciones de Sarduy como una mascota latinoamericana exótica, brindada por Pauls (10), o como un aditamento pintoresco en la vanguardia cubana, escrita por Cozarinsky (124). 
varias de ellas transformadas con respecto a la versión de Cervantes. Por ejemplo, se lo muestra cobarde ante un caballero sueco, al que debía enfrentar por solicitud de la princesa Micomicona, después de haber recibido la promesa de gobernar China (Chartier, Cardenio 86; véase también Canavaggio 47; Cioranescu 526; Jurado 25).

Esa relación plástica con la novela es tal que sus personajes no solo comienzan a aparecer en los escenarios teatrales, sino incluso son aludidos en otras versiones francesas de otras novelas españolas. En esa línea, Chartier indica que la primera traducción de El Buscón de Quevedo caracteriza el caballo de uno de los personajes como un Rocinante, a la vez que se refiere a la barba de Sancho Panza, detalles ambos inexistentes en el texto español de Quevedo ("La Europa" 141).

Esta posibilidad de leer Don Quijote con la libertad que le brinda la clave humorística permite la persistencia de la obra en las letras francesas. El clásico libro de Bardon describe tales recorridos de manera exhaustiva. A diferencia del triste desinterés que genera la literatura española ante las letras clásicas e ilustradas en Francia, Don Quijote pervive en clave cómica, acaso como crítica de la literatura española. En efecto, Montesquieu hace decir a uno de sus personajes el contraste entre Cervantes y la cultura española: "El único de sus libros que es bueno es el que hace ver el ridículo de todos los otros" (250).

Exagere o no a través de la ficción, se defiende allí a la novela de Cervantes como antídoto ante los excesos de la ficción. La posterior apertura romántica a la ficción desplaza ese tipo de lectura, algo pedagógica. Durante el siglo XIX, algunos de los más importantes escritores en lengua francesa destacan la importancia de la novela cervantina como una obra precursora de sus distintas tentativas literarias. Así, Hugo lee en la novela la combinación de filosofía y comicidad (281), Stendhal la posibilidad de reír a escondidas de su padre (619), Sade la combinación de narración y pedagogía $(X, 67)$ y Flaubert la mezcla de la ilusión y la realidad (II, 168).

Si nos interesa indicar tan groseramente esas posiciones es con el objetivo de subrayar la plasticidad que presenta Don Quijote a la hora de construir distintas agendas para la literatura moderna. Ello abre la posibilidad de leer en tal novela una reflexión sobre la literatura, posibilidad que recorren en Francia, antes de Sarduy, dos de los más notables lectores de Flaubert: Marthe Robert y Michel Foucault, cuyas lecturas marcan la discusión sobre Don Quijote en Francia durante los años sesenta (Scaramuzza).

La primera, una notable crítica y traductora que merece más atención en la crítica hispanoamericana, publica en 1963 L'ancien et le nouveau: de Don 
Quichotte à Franz Kafka. Su obra resalta el carácter moderno de la novela cervantina, la primera en incluir al autor dentro de la obra (24). Lejos de narrar la historia de otro narrador, como pueden hacerlo obras posteriores, en la obra de Cervantes se narra quien narra. La novela moderna nace entonces tematizando sus propias condiciones, insistiendo una y otra vez en la relación de los personajes con la lectura. Para Robert, el carácter moderno de la ficción cervantina no se juega en sus eventuales contenidos, sino en la desestabilización que establece entre el sujeto y su narración.

También Foucault lee la novela de Cervantes como cierta clave para comprender una nueva relación entre el sujeto y la escritura. En variados

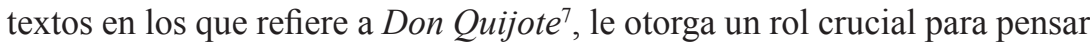
la modernidad desde su relato de la historia de la locura. Foucault lee la historia del Quijote como expresión del triunfo trágico de la razón contra la locura. Cervantes mostraría la incomprensión del mundo moderno ante el loco, a quien ni siquiera se le permite enunciar su propia verdad, la que solo la literatura puede narrar y castigar. Así, Foucault lee en la escena de muerte del Quijote otro momento de locura del personaje ("Histoire" 50).

Foucault presenta también ese análisis en la radio, al menos en dos ocasiones. En la primera, realizada después de la publicación del libro recién citado, subraya el influjo de la fiesta popular medieval en la novela ("Don Quichotte"). El vínculo entre la fiesta y la novela no pasa porque la segunda represente la primera, sino porque la escritura literaria hereda la posibilidad de la fiesta en un ejercicio en el que la lengua remite y juega consigo mismo, en cierto exceso en la significación que luego prolongan y radicalizan las obras literarias que le interesan a Foucault, como las de Blanchot, Klossowski o Roussel.

Sin embargo, a diferencia de estos últimos autores, Foucault asume que el repliegue de la lengua en Cervantes no desarma la razón. Si bien la novela expresa la literatura dentro de la literatura ("La littérature" 91), sortea ese vértigo con una risa que ríe de la locura sin dejarse implicar por ella. La lengua no se repliega en la ficción, sino que describe sus efectos con cierta distancia, con la razón que el novelista mantiene y refuerza.

En algunos de esos textos, y también en otros que no remiten a Cervantes, Foucault escribe también sus lecturas sobre Sade y Flaubert. Habría que ver hasta qué punto esas lecturas pueden pasar, o no, por lecturas compartidas de Don Quijote. 
En efecto, en la segunda conferencia radial sobre la obra, grabada en 1963, Foucault modifica parcialmente su lectura del final de la novela, pero para confirmar el racionalismo que supone en la obra. Según apunta, el personaje se hace consciente de su previa locura como si hubiera sido una fiebre. Locura y razón se establecen entonces como la vida y la muerte, sin continuidad posible ("Le langage" 35).

En ese sentido, el personaje logra superar las confusiones gracias al saber de la razón, el mismo que permite al novelista escribir la ficción. Esto es, el conocimiento de la separación de las palabras y las cosas, parafraseando el título del volumen, que se publica el mes de la conferencia de Sarduy y que rápidamente se convierte en un libro imprescindible de acuerdo al rastreo realizado por Compagnon de la coyuntura cultural de ese año. Foucault allí expone su última y más conocida lectura de Cervantes. Publicado el mismo año que la conferencia de Sarduy, quien por cierto lo cita en diciembre de ese año en un ensayo sobre García Márquez ("L'écriture" 3), el libro también caracteriza a Don Quijote como la primera obra moderna, dada su capacidad de afirmar el irreductible hiato entre las palabras y las cosas que abre el mundo moderno.

"Largo y flaco como una letra", remarca Foucault, probablemente pensando en la consonante que abre los nombres de Quijano y Quijote, la novela narra la historia de quien se impone otro nombre que busca ser coherente con su propio cuerpo, pues insiste en la búsqueda de la correspondencia perdida entre las palabras y las cosas. Cree contar con un saber que desenmascara el mundo, pero su historia muestra que no hace más que enmascararlo, que enmascararse. El Quijote resulta así un ser de letras que cree ser real, que supone que es el nombre, o acaso la letra, lo que le permite ser Quijote o Quijano. En el encierro o a la intemperie, el personaje se rige por otra ley, incomprensible en el mundo moderno. El Quijote, apunta Foucault, vive cierta soberanía solitaria ("Les mots" 1095).

En la ficción del poder que no tiene, el Quijote puede al menos darse a sí mismo la posibilidad de imponer una lengua para sí. Es con ella que ha de resistir, contra los saberes del mundo moderno, inclusive quizá contra los de Cervantes. Desde una lectura algo gruesa de la modernidad, para Foucault el barroco no resiste al mundo moderno ${ }^{8}$.

8 En una conferencia brindada por esos años, recientemente recuperada, Foucault presenta más claramente esta lectura del barroco español, que no distingue del todo del barroco 


\section{DE DÓNDE SON LOS QUIJOTES}

Puede que la creatividad de la lectura que realiza Sarduy de Don Quijote se explique, al menos parcialmente, por su capacidad de combinar las preguntas abiertas por la crítica francesa con la celebración cubana del humor cervantino, que Sarduy puede pensar al alero de las ideas que despliega sobre el barroco. Se trata así de pensar en la reflexividad de una novela que al pensarse a sí misma muestra su distancia ante sí misma, jugando en ella sin castigar a nadie.

Desde el arranque de la conferencia, Sarduy explicita que no toda la obra despliega un claro significado de la búsqueda por el significado. En la figura de Sancho lee cierta opacidad que parece abrir en la novela distintas estrategias ante la significación, no todas ellas trágicas. Así, para Sarduy el hiato entre las palabras y las cosas permite la ficción como un tipo de arte que recorre y exhibe, con alegría, las palabras sin las cosas. La ficción literaria emerge como cierto juego de la lengua en la lengua, que se afirma gracias, y no pese, a su imposibilidad de distinguir con claridad la realidad de la ficción.

Para mostrar la radicalidad de la invención cervantina, la presentación de Sarduy se detiene en dos momentos no tan célebres de la primera parte de Don Quijote. Se trata de dos lugares que justamente tematizan la relación entre la obra y la ficción, contrastando, aparentemente, con partes más conocidas de la novela, en las que se describen los acontecimientos que pareciera que sí suceden a los personajes -por ejemplo, la lucha contra los molinos o el gobierno de Sancho Panza-.

Sarduy se interesa particularmente en los momentos en los que Cervantes juega con la inserción de otra novela en la novela, recordando el diálogo que precede a los capítulos en los que se presenta la historia de El curioso impertinente. Como es sabido, desde la aparición del primer volumen de Don Quijote ese gesto de Cervantes ha sido discutido y criticado, dada la aparente falta de relación de esa historia con la estructura general de la novela. A diferencia de las otras historias intercaladas, cuyos personajes y efectos se entrecruzan con las del Quijote, esta historia se lee y sus personajes son, dentro de la ficción, ficticios.

Entre esos críticos tempranos del gesto de Cervantes están Sancho y el Quijote. Al comienzo de la segunda parte de la novela, se enojan cuando

francés. El texto presenta en Cervantes la literatura como una especie de espejo controlado, un artificio sin locura. Para mayor detalle, véase al respecto ("La littérature et la folie" 93 y ss.). 
Sansón Carrasco les cuenta que el popular libro sobre sus gestas cuenta con esa historia. El primero lo acusa de mezclar de más, mientras el segundo lo acusa de falta de claridad con una curiosa argumentación:

No ha sido sabio el autor de mi historia, sino algún ignorante hablador, que a tiento y sin algún discurso se puso a escribirla, salga lo que saliere, como hacía Orbaneja, el pintor de Úbeda, al cual preguntándole qué pintaba respondió: "Lo que saliere". Tal vez pintaba un gallo de tal suerte y tan mal parecido, que era menester que con letras góticas escribiese junto a él: "Este es gallo". Y así debe de ser de mi historia, que tendrá necesidad de comento para entenderla (571).

Con mayor gracia que sus críticos, el personaje da cuenta de una objeción compartida: la historia de El curioso impertinente es impertinente en la obra. A diferencia de las otras historias, aparentemente naturales a la continuidad del relato, esta historia se presenta como un antojo innecesario. Desvía la centralidad de sus heroicas gestas, al punto de que siglos después aburre al gobernante cubano que quiere inspirarse en ellas.

En el siglo XX, la crítica de la novela ha intentado pintar esas letras góticas, explicando por qué la novela resulta necesaria para corroborar o contrastar algunas posiciones morales o epistemológicas de los personajes que sí formarían parte de la obra (cfr. las lecturas recordadas por Abud 4-9, Percas de Ponsetti 182 y ss., Van Beysterveldt 144 y Wardropper 587-588). En uno y otro caso, se asume que Cervantes ha debido insertar la historia por cierta necesidad interna de una estructura que se refuerza, si es que no se completa, sin vacíos ni arbitrariedades.

Frente a ese tipo de lecturas, Sarduy asume que la única necesidad de una novela en la novela es la de mostrar la arbitrariedad en la ficción, y así la posibilidad de cualquier novela en cualquier novela. Para mostrarlo, recuerda un diálogo en el que cada uno de los personajes de la venta explica su implicación con la ficción a partir de sus particulares fantasías.

La pertinencia de tales capítulos es la de remarcar los distintos placeres ante la ficción. En uno de los momentos en los que el Quijote no está en la escena relatada, los otros personajes se libran también a discutir acerca de la importancia de la ficción. No es solo el Quijote, entonces, quien habita el mundo obsesionado por las ficciones que lee. De hecho, casi no hay personaje en la novela cuya vida no esté atravesada por alguna fantasía de difícil consecución. La diferencia de la fantasía quijotesca es su carácter fijo, al punto 
de que cuando es derrotado como caballero andante debe inmediatamente amoldarse a otra fantasía, la de la vida pastoral.

Los otros personajes permiten que sus fantasías se desplacen y convivan con otras, lo que les permite comprender la historia de El curioso impertinente como una obra de ficción. Ante ella, como ante casi cualquier relato que se presenta en la obra, discuten acerca de qué o cómo debiera contarse. El talento en el relato no pasa por tener alguna historia que contar, sino por escoger cuál y de qué manera.

El mundo inventado por Cervantes es así un mundo cuyas experiencias se viven para ser relatadas, abriendo infinitos relatos sobre relatos, y otras tantas discusiones acerca de cómo deberían relatarse. De hecho, en la segunda parte, los personajes no solo discuten la primera parte de novela, como en el diálogo con el bachiller Carrasco acerca de El curioso impertinente, sino que además cambian sus trayectos para desmentir la obra que supuestamente relata sus acciones.

De esta manera, la presencia de la obra en la obra marca y desvía la obra. Sarduy establece allí cierta analogía con Las meninas. La analogía no es inédita: aparece, por ejemplo, en Riley (48), y por cierto en Foucault ("Les Mots" 1047 y ss.), quien con tal pintura plantea el estatuto moderno de la representación. Sarduy, por el contrario, parece leer en una y otra obra el fracaso de cualquier tentativa de la representación que desee no estar implicada en ella. Así, para subrayar que los personajes de Don Quijote leen Don Quijote, indica que el pintor en Las meninas está pintando Las meninas.

Con esa conjetura, Sarduy no solo remarca que el autor es inventado por la obra. De manera más radical, pone la obra en la obra. Al no poder corroborarse, y así no poder corroborar ninguna presencia, la escritura solo puede jugar con el propio modelo que se da, mostrando cómo ella se implica y desfigura a sí misma en ella misma9 .

Así, Sarduy selecciona una segunda parte de la novela que muestra cómo este fallo de la reflexividad abre la ficción. En ese mundo lleno de relatos, quien narra ese mundo debe también relatar sus dificultades para dar con su relato. Se trata del momento en que quien narra reconoce no tener los papeles

\footnotetext{
$9 \quad$ Evidentemente, esta posición podría leerse en contraste a la conocida lectura foucaultiana de Las meninas, quizá del lado de la no tan célebre lectura lacaniana del cuadro de Velázquez. Como bien explica Rambeau (65 y ss.), Lacan lee allí la imposibilidad de una representación sin fallas, antes que el sujeto moderno que cree poder representar.
} 
para seguir narrando esa historia que gustaría de conocer y narrar. Recién en el noveno capítulo, de una novela que en esa primera versión tiene cincuenta y dos, se ha quedado sin más que contar.

Sin embargo, ávido de leer cualquier cosa, el narrador pronto da con restos de la historia que sigue. No está escrita en una maleta perdida, como el relato de El curioso impertinente, sino en unos papeles destinados a ser comida de gusanos (Piñar 27). Esos papeles escritos en árabe tienen la historia que le falta, lo que quien narra sabe porque un joven que lee esa lengua ríe con una anotación al margen de la historia, que destaca el talento de Dulcinea para salar puercos.

La historia puede seguir gracias al reconocimiento de una risa, producida por una anotación al margen en un texto escrito en otra lengua. Lejos de toda épica y de todo monolingüismo, ese mundo lleno de ficciones solo puede continuar el relato gracias a la incerteza de otra risa y otra lengua. El relato en el que cierto hispanismo busca sellar la identidad hispánica requiere así de lo que esos discursos hispanistas quisieran expulsar. La narración de Don Quijote no solo necesita de un cronista árabe, sino también de su inquietante traducción.

En su comentario de este pasaje, Sollers describe cierto doblez en el relato, ante el cual Cervantes querría asegurar la paternidad de su mito (26). Según deja entrever, Cervantes hace coexistir distintos narradores que logra administrar. Sin embargo, ya en el prólogo Cervantes plantea su desconfianza ante cualquier deseo de una narración, o de una narración de narraciones, que asegura su paternidad. Como "padrastro" de la novela se describe.

Es curioso que Sarduy identifique a Cervantes con ese narrador sin texto, como si el autor de la novela ingresara en la narración en la que antes ya se lo nombrado como autor de otras obras. En lugar de pensar al o los narradores de Don Quijote como personajes inventados por Cervantes, Sarduy parece leer allí la confesión de la ficción como un relato posibilitado por cierto no saber. De esta manera, Cervantes abre la ficción moderna como una crítica de cualquier relato de una filiación que pudiera asegurar un relato simple de la reproducción ${ }^{10}$. La novela, de ahí en adelante, pasa a ser la historia de

10 También en este punto puede leerse la distancia de Sarduy ante quienes creen que el carácter crítico de la obra de Cervantes pasa por su capacidad de establecer una crítica certera del orden social. Osterc, por ejemplo, comenta este capítulo indicando que la desconfianza ante el narrador arábigo le permite a Cervantes sortear la censura y criticar las instituciones 
un narrador que debe proseguir una historia que desea y desconoce, entre fragmentos, traducciones, conjeturas y testimonios que no calzan del todo entre sí. Antes de la versión de Avellaneda, de hecho, la primera parte cierra señalando que hay quienes saben de otros episodios del caballero.

Si puede haber alguna heroicidad en Don Quijote, entonces, está en el rol de quien narra, que logra sobreponerse a las dificultades y engaños de los archivos con los que debe proseguir la historia. Harto avanzada la segunda parte, debe contar que el traductor no ha traducido adecuadamente a Cide Hamete Benengeli para protestar contra la monotonía de una historia basada en el Quijote y Sancho, carente de digresiones y episodios más graves y entretenidos, como lo era por ejemplo la historia de El curioso impertinente. Ante ello, la proeza no está en poder contar un relato, que los hay, sino en escoger qué y cómo contar: "y pues se contiene y cierra en los estrechos límites de la narración, teniendo habilidad, suficiencia y entendimiento para tratar del universo todo, pide no se desprecie su trabajo, y se le den alabanzas, no por lo que escribe, sino por lo que ha dejado de escribir" (Cervantes 878).

\section{MAGIAS PARCIALES DE BORGES}

LOS FRAGMENTOS SELECCIONADOS POR SARDUY DAN CUENTA DE CIERTA COMPRENSIÓN DE Don Quijote como una ficción capaz de tematizar el estatuto de la ficción y poner en jaque algunas de las distinciones que la posterior crítica literaria ha deseado imponer sobre la novela cervantina, tales como las oposiciones entre realidad y ficción, entre escritura y lectura, entre original y copia. La forma misma de la novela juega a enredar y desenredar tales binomios. Al centrarse en los juegos de la narración, Sarduy se distancia de las tradicionales lecturas que leen la novela como la exposición de cierta antropología o psicología, individual o nacional.

Renuente a cualquier mimetismo, la novela pide ser leída como un juego de la lengua, abierta a la reescritura que ya no se preocupa por representar algún tiempo o espacio determinado. Esta capacidad de la ficción de sobrepasar tales límites de la realidad le permite a Sarduy destacar la existencia de posteriores fragmentos de Don Quijote en América. Existiendo

dominantes (80), como si Cervantes no solo contara con el saber de la historia sino también con el de una narración que puede ocultar la crítica y luego ser desocultada por la lectura crítica. 
ya traducciones francesas de lecturas de Cervantes tan influyentes como las de Castro, Lukács o Unamuno, y existiendo también cierta producción francesa sobre Don Quijote en textos como los de Bataillon o Vilar, Sarduy opta por inscribir la lectura de Cervantes en cierta deriva latinoamericana en la que lee un posicionamiento más flexible, cuando no antagónico, con el hispanismo. Se trata de cierta distancia creativa que ha abierto la posibilidad de constantes reescrituras de la novela de Cervantes, lo que Borges lleva al límite al reescribir su escritura como su reescritura.

En el momento en que Sarduy presenta su conferencia, Borges es ya un escritor de interés dentro del pensamiento francés de avanzada (cfr. Hidalgo; Lafon). Aparentemente lejano a la cultura latinoamericana, su literatura es entonces cuestionada por cierto refinamiento que se liga a la cultura francesa. Sarduy, de hecho, lo defiende ante ciertos cuestionamientos que lo leen como un autor supuestamente afrancesado (I, 27). Por ejemplo, en un texto crucial publicado en Cuba poco después, Fernández Retamar grafica a Borges como un típico escritor colonial (52) -poco antes, por cierto, de cuestionar los "mariposeos neobarthesianos" de Sarduy (60)-.

La defensa que hace Sarduy de una posición como la de Borges pasa por su desplazamiento de los supuestos de Fernández Retamar. Allí donde este último podía contraponer una literatura latinoamericana arraigada a una literatura colonialista desarraigada, Sarduy piensa la literatura latinoamericana en el desarraigo, en la posibilidad de revolver el archivo de Occidente en el que se inscribe de manera lateral. Borges toma así Don Quijote como un material de la ficción antes que como un documento histórico de la lucha por la liberación. Si para Borges ese gesto poco se relaciona con la política, a la que pide más bien la tranquilidad para que pueda desplegarse una ficción que no la toque, para Sarduy la ficción abre cierta política consistente en la liberación de las exigencias de la realidad histórica. Con ello, abre paso a la posibilidad de otra relación con la lengua, en la lengua, ya no sometida a la economía del mundo, en la cual puede abrirse el juego barroco.

Con esa defensa de la ficción, Sarduy rescata de Borges cierta concepción de la literatura, y no tanto una escritura literaria ${ }^{11}$. A saber, una concepción de

11 Evidentemente, este punto abre también la posibilidad de leer a Borges con Sarduy, recorrida por trabajos como los de Jill Levine, quien recuerda que las tematizaciones del barroco en Sarduy pasan por Borges (93). Posteriormente, Rivero-Potter ve cierta afinidad en las referencias metaficticias y la ambigüedad narrativa (119), mientras que Filer concluye 
la literatura que descree de cualquier tipo de referencia. La lectura borgiana de Don Quijote radicaliza esta posición al argumentar que los juegos cervantinos llevan a dudar acerca de la realidad de quienes leen la novela, cautivos del juego de ilusiones que abre Don Quijote.

En ese sentido, la ficción sobre Pierre Menard que se lee también en la emisión radial puede interpretarse como uno de los tantos pliegues posibles de la novela. Sin espacio para comentar cómo se anuda el autor francés inventado por Borges con la lectura de Cervantes que presenta en francés Sarduy, nos limitamos a recordar que uno de los capítulos que copia Menard es justamente el noveno. También Borges subraya en Cervantes algunos momentos en los que tematiza la literatura como desvío en la repetición, esa que ejecuta Menard. Como bien explica Gamerro, el hecho de que el francés escriba Don Quijote y no otra obra del canon puede ligarse a la existencia de relatos sobre el relato de Don Quijote en Don Quijote (143).

Relato sobre un relato sobre relatos, y así hasta el infinito, la ficción sobre Pierre Menard muestra la contemporaneidad del gesto cervantino, esto es, la posibilidad de un tiempo de la ficción que no calza con ningún presente. Al hacer caer la letra sin certeza, el clinamen de la ficción forma uno y otro mundo, una y otra vez. Así parece haberlo pensado Sarduy, por cierto, al retratar a Borges en el poema que le dedica: "un juego/ de sílabas ardientes, que al extremo/ de su caída en el vacío adverso/ se decantan en forma de universo" (I, 218).

su trabajo destacando también la afinidad de ambos por la parodia (226). Estas cercanías, que por cierto pueden leerse a partir de la fascinación de Borges y de Sarduy por Don Quijote, no son falsas, pero sí algo genéricas. La pregunta que habría que recorrer, nos parece, es la de cómo una y otra escritura asumen la ambigüedad y la parodia, ya que la apuesta escritural de Sarduy pasa por una estrategia del exceso, muy distinta a la sobriedad de Borges, crítico del barroco. Nos parece que quien ha abordado de forma más lúcida esa diferencia es Carlos Gamerro, quien en Ficciones barrocas distingue entre escritura barroca y ficción barroca, poniendo a Sarduy del lado de los primeros (33) y a Borges de los segundos (41). A partir de su lectura, podría incluso pensarse que es en nombre de la ficción barroca que Borges busca limitar cualquier barroquismo en la escritura. No es claro, sin embargo, que desde Sarduy puede hacerse esa distinción, ya que para el escritor cubano la falta barroca de claridad ha de pasar también por la opacidad en la escritura. 


\section{MAGIAS IMPARCIALES DEL BARROCO}

Si bien algunas de nuestras disquisiciones exceden lo que Sarduy sostiene en la conferencia radial, nos parece que pueden ayudar a comprenderla, y sobre todo a entender la importancia que puede haber tenido Don Quijote a la hora de pensar las relaciones de Sarduy con la literatura y la ensayística latinoamericana. Al leer la novela cervantina en cierta continuidad con las lecturas ya realizadas por la literatura barroca cubana, Sarduy la recupera dentro del linaje discontinuo entre el Siglo de Oro español y la literatura cubana contemporánea en el que Sarduy se emplaza (Guerrero 95).

Subrayar que, para Sarduy, Don Quijote forma parte del barroco permite sobrepasar una lectura que limite el interés de Sarduy por el barroco español a Góngora o a la poesía ${ }^{12}$. En efecto, sus comentarios sobre Don Quijote prosiguen tras la conferencia radial, a la vez que su relectura de Don Quijote dura toda su vida (Wahl 1462).

La novela de Cervantes brinda así a Sarduy una clave con la cual seguir leyendo el barroco cubano y, con ello, el porvenir de la literatura latinoamericana. Con Lezama Lima, cuestiona a quienes critican al Quijote por confundir la vida y los libros, puesto que la vida no ha de pensarse al margen de la literatura (II, 1419).

Don Quijote no solo permite pensar una ficción hospitalaria a la ficción, sino particularmente una vida que no se deja separar del todo de ella. Y, por lo mismo, una vida donde ya nada podría ser lo mismo. En otro momento, retoma la cuestión de la novela en la novela para explicitar que ese pliegue no remarca más, ni menos, que su distancia: "La obra está en la obra, es verdad -como en el Quijote y en Las meninas - para subrayar su alteridad, obra no traducida, virada al revés, para siempre ilegible" (II, 1240).

Esa pérdida de la obra abre la posibilidad de su reescritura, incluyendo las de varias obras ya mencionadas. De ahí que Sarduy se valga de Don Quijote como el mejor ejemplo para pensar la parodia, en tanto carnavalización que hereda el barroco latinoamericano (II, 1394; cfr. "Conversation" 142). Lejos de ver allí una representación realista del carnaval, Sarduy celebra una escritura capaz de parodiarse, como la de Borges, pero también tentativas

12 Por ejemplo, González Echeverría se jacta de que el interés de Sarduy por Gracián, Quevedo y Calderón nace de las conversaciones que él habría tenido con Sarduy. Como buen liberal, parece suponer que cada quien tiene el derecho a decir lo que quiere. 
harto distintas. Así, destaca esa operación en la obra de Puig, abierta a confusiones y profanaciones, excentricidades y ambivalencias que tienen como privilegiado antecesor a Don Quijote ("Notas" 557).

De acuerdo con Sarduy, la parodia ríe de los géneros de escritura a través de injertos e intrusiones de un discurso en otro. No se trata entonces de reír de una realidad determinada, sino de suturar la posibilidad de determinar cualquier límite claro entre la realidad y la ficción, y así sobre los géneros de la ficción. En su ensayo sobre García Márquez, subraya cierta tradición hispánica, abierta por Don Quijote, de presentar la escritura como desciframiento de otra escritura, lo que reivindica su autonomía, barrando cualquier exterioridad ("L'écriture" 3).

La novela en español que le interesa a Sarduy, de Cervantes en adelante, parece ser la historia de ese ejercicio. Contra cualquier rescate patrimonial, contra cualquier historicismo, Sarduy puede leer entonces a Cervantes como un contemporáneo, entre un "nosotros" que desafía cualquier delimitación de alguna colectividad en nombre de la época, el género o la lengua. Con deliberado anacronismo, celebra una novela que sobrevive en la actualidad por su insistente inactualidad, su curiosa impertinencia.

\section{OTRO LUGAR DE LA MANCHA}

No quisiéramos terminar esta ya excesiva presentación sin remarcar un eventual, inesperado eco de la reflexión de Sarduy en la obra de Lacan. Si bien el psicoanalista presenta mayor interés por el barroco español que sus contemporáneos franceses -“yo soy el Góngora del psicoanálisis", escribe en 1957 ("Situation" 467)-, pareciera que jamás menciona ni a Cervantes ni a Sarduy. Sin embargo, es tentador leer el eco del Cervantes de Sarduy en uno de los momentos en los que Lacan explica la lengua.

En la sesión que dedica al barroco en su seminario de 1973, el psicoanalista distingue el pensamiento y lo pensado, argumentando que el pensamiento está del lado del manche (Encore 96), lo que Rabinovich traduce como pensamiento del mango (129). El pensamiento cree poder controlar la lengua y dar así con cierto saber certero. Lacan vincula esa capacidad de control del pensamiento a la palabra, jugando con la homofonía para transformarlo ese mango dicho (dit manche) en domingo (dimanche), ese que Kojève celebraba como el domingo de la vida propio del saber absoluto, domingo cuyo arte 
por cierto para Hegel (643) era la pintura flamenca, cierta representación de la vida burguesa cotidiana, renuente a los excesos del barroco español.

Lacan busca pensar otro domingo, ni tan dirigido por el saber laboral de la semana ni tan tranquilo como el descanso burgués. Su pintura ya no puede ser la de sujetos más o menos claros u oscuros, ni siquiera en el claroscuro, sino en la tensión que instala el barroco como no saber en medio de la luz. Lacan declara que se pone del lado del barroco, de esa historieta de Cristo, de cierto goce en una lengua que no se sabe.

Se trata de un arte, según Lacan, que ya no se sitúa en el lado de le manche, sino de la manche (Encore 97). Rabinovich traduce ese desplazamiento de género como el paso del mango a la manga, a cierto juego de manos marcado por el no-todo de la posición femenina que tematiza en tal seminario. Manche, en efecto, indica en lengua francesa cierta ronda de juego. También, por cierto, es la forma de traducir "La Mancha".

El juego de la lengua en la lengua puede así aludir a esa lengua que, en Cervantes, si es leído con Sarduy, abre un lenguaje que no se sujeta por ningún saber, en esa novela que se abre con una narración que quiere no recordar algún lugar determinado de La Mancha para inventar un escrito lleno de manchas. Nada podría probar que Lacan, tan presto a jugar con los equívocos como a confesarlos, haya también pensado en Don Quijote a la hora de pensar la manche. Es plausible que ese posible encuentro en la lengua no haya sido más, pero tampoco menos, que un alegre azar. 


\section{CERVANTES ENTRE NOSOTROS ${ }^{13}$ Severo Sarduy}

Hablar de la actualidad de Cervantes es hablar directamente de la literatura. La obra de Cervantes es el momento donde se fija la sintaxis de una lengua, pero sobre todo el momento en el que una relación esencial se muestra: la del artista con su obra. Libro de un género literario, la novela de caballería -de la cual es la apoteosis y no solamente la crítica-, libro de una lengua, Don Quijote es también el libro que plantea la pregunta capital de todo creador: ¿Cuál es la relación de la realidad con la ficción? ¿En qué medida somos capaces de percibir la realidad, cuál es el valor de la palabra, del lenguaje?

La indagación sobre el lenguaje, de hecho, es el tema mismo de Don Quijote, libro que es un microcosmos lingüístico, una reducción. Vamos a ver la importancia de ese mecanismo en la obra cervantina, del macrocosmos de la lengua real. Desde el lenguaje corriente hasta el estilo filosófico, el libro recorre, reduce toda la estructura lingüística del español, pero se extiende también entre dos polos en el nivel de la significación. Por un lado, la transparencia del significante para el Quijote, que hace referencia solamente a una dimensión ficticia. Por otro lado, la opacidad del significado en Sancho, que remite al nivel más simple de la realidad y el idiolecto, y está casi totalmente constituido por dichos, proverbios y frases de estilo barroco.

Pero la reducción fundamental de Don Quijote no es la de la lengua, sino del libro mismo. Del libro, en tanto que objeto y en tanto que reflejo del mundo. También en este sentido sus preocupaciones son totalmente actuales.

13 No contamos con registro del texto leído por Sarduy, de modo que tradujimos directamente de la emisión del programa, disponible en el sitio web de France Culture, sin transcribir la introducción ni las breves opiniones de Sollers. Algo abusivamente, hemos añadido las puntuaciones y separado los párrafos donde nos ha parecido sensato hacerlo. Como ya lo hemos hecho en la introducción, escribimos con cursivas Don Quijote cuando Sarduy alude a la novela, y sin cursivas cuando refiere al personaje, aun cuando la presentación de Sarduy tematiza la dificultad de mantener esa distinción. Dejamos también en cursiva los textos de Cervantes y Borges que son leídos en la transmisión en francés. En el caso del primero, se utiliza la traducción de Louis Viardot. En el del segundo, la de Paul Verdevoye. Insertamos aquí los textos en español. Para Don Quijote, tomamos la versión dirigida por Francisco Rico, citada en la bibliografía. La primera parte corresponde a las páginas 320-327 y la segunda a las páginas 85-87. Los textos de Borges, por su parte, se siguen de la edición de las Obras Completas publicadas en Buenos Aires por Emecé en 1991. En concreto, las páginas 45-47 del tomo II y 444-450 del tomo II. 
Como sabemos, el siglo XX ha reactivado, sobre todo en los pasos abiertos por las obras de Mallarmé y de Joyce, la preocupación del libro como tema al cual consagrar el libro, y como reducción del mundo. A lo que hay que añadir la reducción del mundo mismo concebido como un material de un código entonces descifrable, un material que se da a la lectura.

Don Quijote está escandido por unas imágenes del libro. El ejemplo de La Galatea, libro del propio Cervantes que es juzgado y comentado en la primera parte, es desde entonces célebre. Más interesante es el de El curioso impertinente, novela cuyo título debiera traducirse como Le curieux impertinent y no como Le curieux malavisé, como se lo suele hacer, ya que, como vamos a ver, la historia se trata de la pertinencia.

La inserción de esta novela en Don Quijote ha sido un tema constante de crítica, desde la aparición de la primera parte de la novela hasta nuestros días. El Quijote y Sancho se encuentran en la venta, a la vuelta de una de sus expediciones. Durante la tarde, al abrigo del fuego, los personajes que se encuentran comienzan a hablar acerca de la relación entre la realidad y la ficción. Unos aman la novela y la consideran útil, los otros la condenan y la consideran dañina.

Es en ese momento que se trae una maleta olvidada por un cliente que, como suele pasar en Cervantes, está llena de libros. El cura, interesado, propone leerla. Es entonces que en tres capítulos de Don Quijote vamos a asistir a la lectura de la historia de El curioso impertinente. La historia de la novela, realmente banal, no tiene relación con la del Quijote. ¿Cuál es el propósito, entonces, de su inserción en el libro?

El momento de su inserción da, quizás, la respuesta. Se habla de lo real y de la ficción. Es entonces que los personajes ficticios de Don Quijote logran la acción más real dentro de la vida de un ser real: leer un libro de ficción. Nosotros, en tanto lectores de Don Quijote, somos asimilados a la ficción porque, como los personajes ficticios, nos disponemos a leer una novela de ficción.

Y como el cura dijese que los libros de caballerías que don Quijote había leído le habían vuelto el juicio, dijo el ventero:

-No sé yo cómo puede ser eso, que en verdad que, a lo que yo entiendo, no hay mejor letrado en el mundo, y que tengo ahi dos o tres dellos, con otros papeles, que verdaderamente me han dado la vida, no solo a mí, sino 
a otros muchos. Porque cuando es tiempo de la siega, se recogen aqui las fiestas muchos segadores, y siempre hay algunos que saben leer, el cual coge uno destos libros en las manos, y rodeámonos dél más de treinta y estámosle escuchando con tanto gusto, que nos quita mil canas. A lo menos, de mí sé decir que cuando oyo decir aquellos furibundos y terribles golpes que los caballeros pegan que me toma gana de hacer otro tanto, y que querría estar oyéndolos noches y días.

-Y yo ni más ni menos — dijo la ventera -, porque nunca tengo buen rato en mi casa sino aquel que vos estáis escuchando leer, que estáis tan embobado, que no os acordáis de reñir por entonces.

- Asi es la verdad — dijo Maritornes - y a buena fe que yo también gusto mucho de oír aquellas cosas, que son muy lindas, y más cuando cuentan que se está la otra señora debajo de unos naranjos abrazada con su caballero, y que les está una dueña haciéndoles la guarda, muerta de envidia y con mucho sobresalto. Digo que todo esto es cosa de mieles.

- Y a vos ¿qué os parece, señora doncella? —dijo el cura, hablando con la hija del ventero.

—No sé, señor, en mi ánima — respondió ella—. También yo lo escucho, $y$ en verdad que aunque no lo entiendo, que recibo gusto en oillo; pero no gusto yo de los golpes de que mi padre gusta, sino de las lamentaciones que los caballeros hacen cuando están ausentes de sus señoras, que en verdad que algunas veces me hacen llorar, de compasión que les tengo.

—Luego ¿bien las remediárades vos, señora doncella — dijo Dorotea-, si por vos lloraran?

—No sé lo que me hiciera — respondió la moza —: solo sé que hay algunas señoras de aquellas tan crueles, que las llaman sus caballeros tigres y leones y otras mil inmundicias. ¡Y Jesús!, yo no sé qué gente es aquella tan desalmada $y$ tan sin conciencia, que por no mirar a un hombre honrado le dejan que se muera o que se vuelva loco. Yo no sé para qué es tanto melindre: si lo hacen de honradas, cásense con ellos, que ellos no desean otra cosa.

- Calla, niña - dijo la ventera-, que parece que sabes mucho destas cosas, y no está bien a las doncellas saber ni hablar tanto.

- Como me lo pregunta este señor — respondió ella-, no pude dejar de respondelle.

- Ahora bien — dijo el cura —, traedme, señor huésped, aquesos libros, que los quiero ver-Que me place-; respondió él. 
Y entrando en su aposento, sacó dél una maletilla vieja, cerrada con una cadenilla, y, abriéndola, halló en ella tres libros grandes y unos papeles de muy buena letra, escritos de mano. El primer libro que abrió vio que era Don Cirongilio de Tracia, y el otro, de Felixmarte de Hircania, y el otro, la Historia del Gran Capitán Gonzalo Hernández de Córdoba, con la vida de Diego García de Paredes. Así como el cura leyó los dos títulos primeros, volvió el rostro al barbero y dijo:

- Falta nos hacen aqui ahora el ama de mi amigo y su sobrina.

-No hacen - respondió el barbero-, que también sé yo llevallos al corral o a la chimenea, que en verdad que hay muy buen fuego en ella.

—Luego ¿quiere vuestra merced quemar más libros? — dijo el ventero.

-No más - dijo el cura - que estos dos, el de Don Cirongilio y el de Felixmarte.

- Pues ¿por ventura - dijo el ventero-mis libros son herejes oflemáticos, que los quiere quemar?

-Cismáticos queréis decir, amigo — dijo el barbero-, que no flemáticos.

- Así es - replicó el ventero-. Mas si alguno quiere quemar, sea ese del Gran Capitán y dese Diego García, que antes dejaré quemar un hijo que dejar quemar ninguno desotros.

- Hermano mío - dijo el cura-, estos dos libros son mentirosos y están llenos de disparates y devaneos, y este del Gran Capitán es historia verdadera y tiene los hechos de Gonzalo Hernández de Córdoba, el cual por sus muchas y grandes hazañas mereció ser llamado de todo el mundo "Gran Capitán", renombre famoso y claro, y dél solo merecido ${ }^{14}$.

Oyendo esto Dorotea, dijo callando a Cardenio:

- Poco le falta a nuestro huésped para hacer la segunda parte de don Quijote.

- Así me parece a mí — respondió Cardenio —, porque, según da indicio, él tiene por cierto que todo lo que estos libros cuentan pasó ni más ni menos que lo escriben, y no le harán creer otra cosa frailes descalzos.

- Mirad, hermano - tornó a decir el cura-, que no hubo en el mundo Felixmarte de Hircania, ni don Cirongilio de Tracia, ni otros caballeros semejantes que los libros de caballerías cuentan, porque todo es compostura y ficción de ingenios ociosos, que los compusieron para el efeto que vos decís 
de entretener el tiempo, como lo entretienen leyéndolos vuestros segadores. Porque realmente os juro que nunca tales caballeros fueron en el mundo, ni tales hazañas ni disparates acontecieron en él.

- A otro perro con ese hueso - respondió el ventero - ;Como si yo no supiese cuántas son cinco, y adónde me aprieta el zapato! No piense vuestra merced darme papilla, porque por Dios que no soy nada blanco. ;Bueno es que quiera darme vuestra merced a entender que todo aquello que estos buenos libros dicen sea disparates y mentiras, estando impreso con licencia de los señores del Consejo Real, como si ellos fueran gente que habían de dejar imprimir tanta mentira junta, y tantas batallas, y tantos encantamentos, que quitan el juicio!

-Ya os he dicho, amigo - replicó el cura-, que esto se hace para entretener nuestros ociosos pensamientos; y así como se consiente en las repúblicas bien concertadas que haya juegos de ajedrez, de pelota y de trucos, para entretener a algunos que ni tienen, ni deben, ni pueden trabajar, así se consiente imprimir y que haya tales libros, creyendo, como es verdad, que no ha de haber alguno tan ignorante, que tenga por historia verdadera ninguna destos libros. Y si me fuera lícito agora y el auditorio lo requiriera, yo dijera cosas acerca de lo que han de tener los libros de caballerías para ser buenos, que quizá fueran de provecho y aun de gusto para algunos; pero yo espero que vendrá tiempo en que lo pueda comunicar con quien pueda remediallo, $y$ en este entretanto creed, señor ventero, lo que os he dicho, $y$ tomad vuestros libros y allá os avenid con sus verdades o mentiras, y buen provecho os hagan, y quiera Dios que no cojeéis del pie que cojea vuestro huésped don Quijote.

-Eso no — respondió el ventero-, que no seré yo tan loco que me haga caballero andante, que bien veo que ahora no se usa lo que se usaba en aquel tiempo, cuando se dice que andaban por el mundo estos famosos caballeros.

A la mitad desta plática se halló Sancho presente, y quedó muy confuso y pensativo de lo que había oído decir que ahora no se usaban caballeros andantes y que todos los libros de caballerías eran necedades y mentiras, $y$ propuso en su corazón de esperar en lo que paraba aquel viaje de su amo, y que si no salía con la felicidad que él pensaba, determinaba de dejalle y volverse con su mujer y sus hijos a su acostumbrado trabajo.

Llevábase la maleta y los libros el ventero, mas el cura le dijo:

-Esperad, que quiero ver qué papeles son esos que de tan buena letra están escritos. 
Sacólos el huésped, y, dándoselos a leer, vio hasta obra de ocho pliegos escritos de mano, y al principio tenían un título grande que decía: Novela del curioso impertinente. Leyó el cura para sí tres o cuatro renglones y dijo:

- Cierto que no me parece mal el título desta novela, y que me viene voluntad de leella toda.

A lo que respondió el ventero:

-Pues bien puede leella su reverencia, porque le hago saber que algunos huéspedes que aqui la han leido les ha contentado mucho, y me la han pedido con muchas veras; mas yo no se la he querido dar, pensando volvérsela a quien aqui dejó esta maleta olvidada con estos libros y esos papeles, que bien puede ser que vuelva su dueño por aquí algún tiempo, y aunque sé que me han de hacer falta los libros, a fe que se los he de volver, que, aunque ventero, todavía soy cristiano.

—Vos tenéis mucha razón, amigo — dijo el cura-, mas, con todo eso, si la novela me contenta, me la habéis de dejar trasladar.

- De muy buena gana - respondió el ventero.

Mientras los dos esto decían había tomado Cardenio la novela y comenzado a leer en ella; y pareciéndole lo mismo que al cura, le rogó que la leyese de modo que todos la oyesen.

- Si leyera — dijo el cura-, si no fuera mejor gastar este tiempo en dormir que en leer.

- Harto reposo será para mí - dijo Dorotea - entretener el tiempo oyendo algún cuento, pues aún no tengo el espíritu tan sosegado, que me conceda dormir cuando fuera razón.

- Pues, desa manera - dijo el cura-, quiero leerla, por curiosidad siquiera: quizá tendrá alguna de gusto.

Acudió maese Nicolás a rogarle lo mesmo, y Sancho también; lo cual visto del cura, y entendiendo que a todos daría gusto y él le recibiría, dijo:

- Pues asi es, esténme todos atentos, que la novela comienza desta manera:

En Florencia, ciudad rica y famosa de Italia, en la provincia que llaman Toscana, vivian Anselmo y Lotario, dos caballeros ricos y principales.... volvió Fortuna su rueda y salió a plaza la maldad con tanto artificio hasta allí cubierta, y a Anselmo le costó la vida su impertinente curiosidad.

Poco más quedaba por leer de la novela, cuando del camaranchón donde reposaba don Quijote salió Sancho Panza todo alborotado, diciendo a voces:

- Acudid, señores, presto y socorred a mi señor, que anda envuelto en la más reñida y trabada batalla que mis ojos han visto. ;Vive Dios que ha dado 
una cuchillada al gigante enemigo de la señora princesa Micomicona, que le ha tajado la cabeza cercen a cercen, como si fuera un nabo!

— ¿Qué dices, hermano? — dijo el cura, dejando de leer lo que de la novela quedaba-. ¿Estáis en vos, Sancho? ¿Cómo diablos puede ser eso que decís, estando el gigante dos mil leguas de aquí?

En esto oyeron un gran ruido en el aposento y que don Quijote decía a voces:

—iTente, ladrón, malandrín, follón, que aquí te tengo y no te ha de valer tu cimitarra!

Y parecía que daba grandes cuchilladas por las paredes. Y dijo Sancho:

-No tienen que pararse a escuchar, sino entren a despartir la pelea o a ayudar a mi amo; aunque ya no será menester, porque sin duda alguna el gigante está y a muerto y dando cuenta a Dios de su pasada y mala vida, que yo vi correr la sangre por el suelo, y la cabeza cortada y caída a un lado, que es tamaña como un gran cuero de vino.

- Que me maten - dijo a esta sazón el ventero-si don Quijote o don diablo no ha dado alguna cuchillada en alguno de los cueros de vino tinto que a su cabecera estaban llenos, y el vino derramado debe de ser lo que le parece sangre a este buen hombre.

La imagen del libro aparece otra vez en la primera parte de Don Quijote. Pero esta vez no se trata de un libro escogido al azar, como en el caso de El curioso impertinente, sino del mismo Don Quijote. Esta vez, en un caso ejemplar de reducción, el libro se encuentra enteramente dentro del libro. Es curioso remarcar que, como en Las meninas, la obra que junto a Don Quijote se sitúa en el centro de la hispanidad, interviene el mismo mecanismo.

En Las meninas, Velázquez está pintando Las meninas. Cervantes, paseando por azar en una calle de Toledo, encuentra Don Quijote en traducción árabe.

Estando yo un día en el Alcaná de Toledo, llegó un muchacho a vender unos cartapacios y papeles viejos a un sedero; y como yo soy aficionado a leer aunque sean los papeles rotos de las calles, llevado desta mi natural inclinación tomé un cartapacio de los que el muchacho vendía y vile con carácteres que conocí ser arábigos. Y puesto que aunque los conocía no los sabía leer, anduve mirando si parecía por allí algún morisco aljamiado que los leyese, y no fue muy dificultoso hallar intérprete semejante, pues aunque le buscara de otra mejor y más antigua lengua le hallara. En fin, la suerte 
me deparó uno, que, diciéndole mi deseo y poniéndole el libro en las manos, le abrió por medio, y, leyendo un poco en él, se comenzó a reír.

Preguntéle yo que de qué se reía, y respondióme que de una cosa que tenía aquel libro escrita en el margen por anotación. Díjele que me la dijese, y él, sin dejar la risa, dijo:

-Está, como he dicho, aqui en el margen escrito esto: "Esta Dulcinea del Toboso, tantas veces en esta historia referida, dicen que tuvo la mejor mano para salar puercos que otra mujer de toda la Mancha".

Cuando yo oi decir "Dulcinea del Toboso", quedé atónito y suspenso, porque luego se me representó que aquellos cartapacios contenían la historia de don Quijote. Con esta imaginación, le di priesa que leyese el principio, y haciéndolo ansí, volviendo de improviso el arábigo en castellano, dijo que decia: Historia de don Quijote de la Mancha, escrita por Cide Hamete Benengeli, historiador arábigo. Mucha discreción fue menester para disimular el contento que recebí cuando llegó a mis oídos el título del libro, y, salteándosele al sedero, compré al muchacho todos los papeles y cartapacios por medio real; que si él tuviera discreción y supiera lo que yo los deseaba, bien se pudiera prometer y llevar más de seis reales de la compra. Apartéme luego con el morisco por el claustro de la iglesia mayor, y roguéle me volviese aquellos cartapacios, todos los que trataban de don Quijote, en lengua castellana, sin quitarles ni añadirles nada, ofreciéndole la paga que él quisiese. Contentóse con dos arrobas de pasas y dos fanegas de trigo, y prometió de traducirlos bien y fielmente, y con mucha brevedad. Pero yo, por facilitar más el negocio y por no dejar de la mano tan buen hallazgo, le truje a mi casa, donde en poco más de mes y medio la tradujo toda, del mesmo modo que aquí se refiere.

Decíamos que el tema del espejo, del reflejo, es característico de la hispanidad. Es allí también que puede reconocerse esa otra hispanidad que es constituida al otro lado del mar, en América. Es en la medida en que la imagen del libro tiene un lugar fundamental en la obra que Borges es un heredero de Cervantes. Pero si Cervantes plantea su novela entre la ficción (el Amadís de Gaula y las otras novelas de caballería) y la realidad (la España de su tiempo), la realidad de Cervantes ha devenido, por su parte, para nosotros una ficción. Una ficción tan potente como la aludida por el autor de Don Quijote. La Mancha, Castilla, mantienen en nuestros mundos imaginarios contemporáneos el lugar que la vaga geografía del Amadis de 
Gaula mantenía para Cervantes: la simplicidad de un paisaje transformado en poesía por la transmutación de la escritura.

Es verosímil que estas observaciones hayan sido enunciadas alguna vez y, quizá muchas veces; la discusión de su novedad me interesa menos que la de su posible verdad. Cotejado con otros libros clásicos (la Ilíada, la Eneida, la Farsalia, la Comedia dantesca, las tragedias y comedias de Shakespeare), el Quijote es realista; este realismo, sin embargo, difiere esencialmente del que ejerció el siglo XIX. Joseph Conrad pudo escribir que excluía de su obra lo sobrenatural, porque admitirlo parecía negar que lo cotidiano fuera maravilloso: ignoro si Miguel de Cervantes compartió esa intuición, pero sé que la forma del Quijote le hizo contraponer a un mundo imaginario poético, un mundo real prosaico. Conrad y Henry James novelaron la realidad porque la juzgaban poética; para Cervantes son antinomias lo real y lo poético. A las vastas y vagas geografías del Amadís opone los polvorientos caminos y los sórdidos mesones de Castilla; imaginemos a un novelista de nuestro tiempo que destacara con sentido paródico las estaciones de aprovisionamiento de nafta. Cervantes ha creado para nosotros la poesía de la España del siglo XVII, pero ni aquel siglo ni aquella España eran poéticas para él; hombres como Unamuno o Azorín o Antonio Machado, enternecidos ante la evocación de la Mancha, le hubieran sido incomprensibles. El plan de su obra le vedaba lo maravilloso; éste, sin embargo, tenía que figurar, siquiera de manera indirecta, como los crímenes y el misterio en una parodia de la novela policial. Cervantes no podía recurrir a talismanes o a sortilegios, pero insinuó lo sobrenatural de un modo sutil, y, por ello mismo, más eficaz. Íntimamente, Cervantes amaba lo sobrenatural. Paul Groussac, en 1924, observó: "Con alguna mal fijada tintura de latín e italiano, la cosecha literaria de Cervantes provenía sobre todo de las novelas pastoriles y las novelas de caballerías, fábulas arrulladoras del cautiverio”. El Quijote es menos un antídoto de esas ficciones que una secreta despedida nostálgica.

En la realidad, cada novela es un plano ideal; Cervantes se complace en confundir lo objetivo y lo subjetivo, el mundo del lector y el mundo del libro. En aquellos capítulos que discuten si la bacía del barbero es un yelmo y la albarda un jaez, el problema se trata de modo explícito; en otros lugares, como ya anoté, lo insinúa. En el sexto capítulo de la primera parte, el cura y el barbero revisan la biblioteca de don Quijote; asombrosamente uno de los libros examinados es la Galatea de Cervantes, y resulta que el barbero es amigo suyo y no lo admira demasiado, y dice que es más versado en 
desdichas que en versos y que el libro tiene algo de buena invención, propone algo y no concluye nada. El barbero, sueño de Cervantes o forma de un sueño de Cervantes, juzga a Cervantes... También es sorprendente saber, en el principio del noveno capítulo, que la novela entera ha sido traducida del árabe y que Cervantes adquirió el manuscrito en el mercado de Toledo, y lo hizo traducir por un morisco, a quien alojó más de mes y medio en su casa, mientras concluía la tarea. Pensamos en Carlyle, que fingió que el Sartor Resartus era versión parcial de una obra publicada en Alemania por el doctor Diógenes Teufelsdroeckh; pensamos en el rabino castellano Moisés de León, que compuso el Zohar o Libro del Esplendor y lo divulgó como obra de un rabino palestiniano del siglo III.

Ese juego de extrañas ambigüedades culmina en la segunda parte; los protagonistas han leído la primera, los protagonistas del Quijote son, asimismo, lectores del Quijote. Aqui es inevitable recordar el caso de Shakespeare, que incluye en el escenario de Hamlet otro escenario, donde se representa una tragedia, que es más o menos la de Hamlet; la correspondencia imperfecta de la obra principal y la secundaria aminora la eficacia de esa inclusión. Un artificio análogo al de Cervantes, y aun más asombroso, figura en el Ramayana, poema de Valmiki, que narra las proezas de Rama y su guerra con los demonios. En el libro final, los hijos de Rama, que no saben quién es su padre, buscan amparo en una selva, donde un asceta les enseña a leer. Ese maestro es, extrañamente, Valmiki; el libro en que estudian, el Ramayana. Rama ordena un sacrificio de caballos; a esa fiesta acude Valmiki con sus alumnos. Estos, acompañados por el laúd, cantan el Ramayana. Rama oye su propia historia, reconoce a sus hijos y luego recompensa al poeta... Algo parecido ha obrado el azar en Las mil y una noches. Esta compilación de historias fantásticas duplica y reduplica hasta el vértigo la ramificación de un cuento central en cuentos adventicios, pero no trata de graduar sus realidades, y el efecto (que debió ser profundo) es superficial, como una alfombra persa. Es conocida la historia liminar de la serie: el desolado juramento del rey, que cada noche se desposa con una virgen que hace decapitar en el alba, y la resolución de Shahrazád, que lo distrae con fábulas, hasta que encima de los dos han girado mil y una noches y ella le muestra su hijo. La necesidad de completar mil y una secciones obligó a los copistas de la obra a interpolaciones de todas clases. Ninguna tan perturbadora como la de la noche DCII, mágica entre las noches. En esa noche, el rey oye de boca de la reina su propia historia. Oye el principio de la historia, que abarca a todas las demás, y también - de monstruoso modo-, a sí misma. ¿Intuye claramente 
el lector la vasta posibilidad de esa interpolación, el curioso peligro? Que la reina persista y el inmóvil rey oirá para siempre la trunca historia de Las mil y una noches, ahora infinita y circular... Las invenciones de la filosofía no son menos fantásticas que las del arte: Josiah Royce, en el primer volumen de la obra The World and the Individual (1899), ha formulado la siguiente: "Imaginemos que una porción del suelo de Inglaterra ha sido nivelada perfectamente y que en ella traza un cartógrafo un mapa de Inglaterra. La obra es perfecta; no hay detalle del suelo de Inglaterra, por diminuto que sea, que no esté registrado en el mapa; todo tiene ahí su correspondencia. Ese mapa, en tal caso, debe contener un mapa del mapa, que debe contener un mapa del mapa del mapa, y asi hasta lo infinito".

¿Por qué nos inquieta que el mapa esté incluido en el mapa y las mil y una noches en el libro de Las mil y una noches? ¿Por qué nos inquieta que Don Quijote sea lector del Quijote, y Hamlet, espectador de Hamlet? Creo haber dado con la causa: tales inversiones sugieren que si los caracteres de una ficción pueden ser lectores o espectadores, nosotros, sus lectores o espectadores, podemos ser ficticios. En 1833, Carlyle observó que la historia universal es un infinito libro sagrado que todos los hombres escriben y leen $y$ tratan de entender, y en el que también los escriben.

Sabemos que existe una tradición del Quijote, así también una de imitaciones, de parábolas, de historias paralelas del Quijote. Desde la aparición de Don Quijote de Avellaneda, plagio del original, hasta Vida de Quijote y Sancho, libro de Miguel de Unamuno que reconstituye toda la novela, los autores de Don Quijote se suceden. Borges, en la nouvelle "Pierre Menard, autor del Quijote", da cuenta de esta versión paralela.

La obra visible que ha dejado este novelista es de fácil y breve enumeración. Son, por lo tanto, imperdonables las omisiones y adiciones perpetradas por madame Henri Bachelier en un catálogo falaz que cierto diario cuya tendencia protestante no es un secreto ha tenido la desconsideración de inferir a sus deplorables lectores -si bien estos son pocos y calvinistas, cuando no masones y circuncisos-. Los amigos auténticos de Menard han visto con alarma ese catálogo y aun con cierta tristeza. Diríase que ayer nos reunimos ante el mármol final y entre los cipreses infaustos y ya el Error trata de empañar su Memoria... Decididamente, una breve rectificación es inevitable.

Me consta que es muy fácil recusar mi pobre autoridad. Espero, sin embargo, que no me prohibirán mencionar dos altos testimonios. La baronesa 
de Bacourt (en cuyos vendredis inolvidables tuve el honor de conocer al llorado poeta) ha tenido a bien aprobar las líneas que siguen. La condesa de Bagnoregio, uno de los espíritus más finos del principado de Mónaco (y ahora de Pittsburgh, Pennsylvania, después de su reciente boda con el filántropo internacional Simón Kautzsch, tan calumniado, ;ay!, por las víctimas de sus desinteresadas maniobras) ha sacrificado "a la veracidad y a la muerte" (tales son sus palabras) la señoril reserva que la distingue y en una carta abierta publicada en la revista Luxe me concede asimismo su beneplácito. Esas ejecutorias, creo, no son insuficientes.

He dicho que la obra visible de Menard es fácilmente enumerable. Examinado con esmero su archivo particular, he verificado que consta de las piezas que siguen:

a) Un soneto simbolista que apareció dos veces (con variaciones) en la revista La Conque (números de marzo y octubre de 1899).

b) Una monografía sobre la posibilidad de construir un vocabulario poético de conceptos que no fueran sinónimos o perifrasis de los que informan el lenguaje común, "sino objetos ideales creados por una convención y esencialmente destinados a las necesidades poéticas" (Nîmes, 1901).

c) Una monografia sobre "ciertas conexiones o afinidades" del pensamiento de Descartes, de Leibniz y de John Wilkins (Nîmes, 1903).

d) Una monografía sobre la Characteristica Universalis de Leibniz (Nîmes, 1904).

e) Un artículo técnico sobre la posibilidad de enriquecer el ajedrez eliminando uno de los peones de torre. Menard propone, recomienda, discute y acaba por rechazar esa innovación.

f) Una monografía sobre el Ars Magna Generalis de Ramón Llull (Nîmes, 1906).

g) Una traducción con prólogo y notas del Libro de la invención liberal $y$ arte del juego del axedrez de Ruy López de Segura (París, 1907).

h) Los borradores de una monografía sobre la lógica simbólica de George Boole.

i) Un examen de las leyes métricas esenciales de la prosa francesa, ilustrado con ejemplos de SaintSimon (Revue des Langues Romanes, Montpellier, octubre de 1909).

j) Una réplica a Luc Durtain (que había negado la existencia de tales leyes) ilustrada con ejemplos de Luc Durtain (Revue des Langues Romanes, Montpellier, diciembre de 1909). 
k) Una traducción manuscrita de la Aguja de navegar cultos de Quevedo, intitulada La Boussole des précieux.

l) Un prefacio al catálogo de la exposición de litografías de Carolus Hourcade (Nimes, 1914).

m) La obra Les Problèmes d'un problème (París, 1917) que discute en orden cronológico las soluciones del ilustre problema de Aquiles y la tortuga. Dos ediciones de este libro han aparecido hasta ahora; la segunda trae como epígrafe el consejo de Leibniz Ne craignez point, monsieur, la tortue, y renueva los capítulos dedicados a Russell y a Descartes.

n) Un obstinado análisis de las "costumbres sintácticas" de Toulet (N.R.F., marzo de 1921). Menard recuerdo declaraba que censurar y alabar son operaciones sentimentales que nada tienen que ver con la crítica.

o) Una transposición en alejandrinos del Cimetière marin, de Paul Valéry (N.R.F., enero de 1928).

p) Una invectiva contra Paul Valéry, en las Hojas para la supresión de la realidad de Jacques Reboul. (Esa invectiva, dicho sea entre paréntesis, es el reverso exacto de su verdadera opinión sobre Valéry. Éste así lo entendió y la amistad antigua de los dos no corrió peligro.)

q) Una "definición" de la condesa de Bagnoregio, en el "victorioso volumen" la locución es de otro colaborador, Gabriele d'Annunzio que anualmente publica esta dama para rectificar los inevitables falseos del periodismo y presentar "al mundo y a Italia" una auténtica efigie de su persona, tan expuesta (en razón misma de su belleza y de su actuación) a interpretaciones erróneas o apresuradas.

r) Un ciclo de admirables sonetos para la baronesa de Bacourt (1934).

s) Una lista manuscrita de versos que deben su eficacia a la puntuación.

Hasta aquí (sin otra omisión que unos vagos sonetos circunstanciales para el hospitalario, o ávido, álbum de madame Henri Bachelier) la obra visible de Menard, en su orden cronológico. Paso ahora a la otra: la subterránea, la interminablemente heroica, la impar. También, jay de las posibilidades del hombre!, la inconclusa. Esa obra, tal vez la más significativa de nuestro tiempo, consta de los capitulos noveno y trigésimo octavo de la primera parte del Don Quijote y de un fragmento del capitulo veintidós. Yo sé que tal afirmación parece un dislate; justificar ese "dislate" es el objeto primordial de esta nota.

Dos textos de valor desigual inspiraron la empresa. Uno es aquel fragmento filológico de Novalis - el que lleva el número 2005 en la edición de Dresden- 
que esboza el tema de la total identificación con un autor determinado. Otro es uno de esos libros parasitarios que sitúan a Cristo en un bulevar, a Hamlet en la Cannebiére o a don Quijote en Wall Street. Como todo hombre de buen gusto, Menard abominaba de esos carnavales inútiles, sólo aptos decía para ocasionar el plebeyo placer del anacronismo o (lo que es peor) para embelesarnos con la idea primaria de que todas las épocas son iguales o de que son distintas. Más interesante, aunque de ejecución contradictoria y superficial, le parecía el famoso propósito de Daudet: conjugar en una figura, que es Tartarín, al Ingenioso Hidalgo y a su escudero... Quienes han insinuado que Menard dedicó su vida a escribir un Quijote contemporáneo, calumnian su clara memoria.

No quería componer otro Quijote -lo cual es fácil-sino el Quijote. Inútil agregar que no encaró nunca una transcripción mecánica del original; no se proponía copiarlo. Su admirable ambición era producir unas páginas que coincidieran palabra por palabra y línea por línea con las de Miguel de Cervantes $^{15}$.

¿Por qué precisamente el Quijote? dirá nuestro lector. Esa preferencia, en un español, no hubiera sido inexplicable; pero sin duda lo es en un simbolista de Nîmes, devoto esencialmente de Poe, que engendró a Baudelaire, que engendró a Mallarmé, que engendró a Valéry, que engendró a Edmond Teste. La carta precitada ilumina el punto. "El Quijote”, aclara Menard, "me interesa profundamente, pero no me parece ¿cómo lo diré? inevitable. No puedo imaginar el universo sin la interjección de Edgar Allan Poe:

Ah, bear in mind this garden was enchanted! O sin el Bateau ivre o el Ancient Mariner, pero me sé capaz de imaginarlo sin el Quijote. (Hablo, naturalmente, de mi capacidad personal, no de la resonancia histórica de las obras.) El Quijote es un libro contingente, el Quijote es innecesario. Puedo premeditar su escritura, puedo escribirlo, sin incurrir en una tautología. A los doce o trece años lo leí, tal vez integramente. Después, he releido con atención algunos capitulos, aquellos que no intentaré por ahora. He cursado asimismo los entremeses, las comedias, la Galatea, las Novelas ejemplares, los trabajos sin duda laboriosos de Persiles y Segismunda y el Viaje del Parnaso... Mi recuerdo general del Quijote, simplificado por el olvido y la indiferencia, puede muy bien equivaler a la imprecisa imagen anterior de un libro no escrito. Postulada esa imagen (que nadie en buena ley me 
puede negar) es indiscutible que mi problema es harto más dificil que el de Cervantes. Mi complaciente precursor no rehusó la colaboración del azar: iba componiendo la obra inmortal un poco à la diable, llevado por inercias del lenguaje y de la invención. Yo he contraído el misterioso deber de reconstruir literalmente su obra espontánea. Mi solitario juego está gobernado por dos leyes polares. La primera me permite ensayar variantes de tipo formal o psicológico; la segunda me obliga a sacrificarlas al texto 'original'y a razonar de un modo irrefutable esa aniquilación... A esas trabas artificiales hay que sumar otra, congénita. Componer el Quijote a principios del siglo diecisiete era una empresa razonable, necesaria, acaso fatal; a principios del veinte, es casi imposible. No en vano han transcurrido trescientos años, cargados de complejísimos hechos. Entre ellos, para mencionar uno solo: el mismo Quijote".

A pesar de esos tres obstáculos, el fragmentario Quijote de Menard es más sutil que el de Cervantes. Éste, de un modo burdo, opone a las ficciones caballerescas la pobre realidad provinciana de su pais; Menard elige como "realidad" la tierra de Carmen durante el siglo de Lepanto y de Lope. ¡Qué españoladas no habría aconsejado esa elección a Maurice Barrès o al doctor Rodríguez Larreta! Menard, con toda naturalidad, las elude. En su obra no hay gitanerías ni conquistadores ni místicos ni Felipe II ni autos de fe. Desatiende o proscribe el color local. Ese desdén indica un sentido nuevo de la novela histórica. Ese desdén condena a Salammbô, inapelablemente.

No menos asombroso es considerar capitulos aislados. Por ejemplo, examinemos el xxxviii de la primera parte, "que trata del curioso discurso que hizo don Quixote de las armas y las letras". Es sabido que don Quijote (como Quevedo en el pasaje análogo, y posterior, de La hora de todos) falla el pleito contra las letras y en favor de las armas. Cervantes era un viejo militar: su fallo se explica. ;Pero que el don Quijote de Pierre Menard -hombre contemporáneo de La trahison des clercs y de Bertrand Russellreincida en esas nebulosas sofisterías! Madame Bachelier ha visto en ellas una admirable y típica subordinación del autor a la psicología del héroe; otros (nada perspicazmente) una transcripción del Quijote; la baronesa de Bacourt, la influencia de Nietzsche. A esa tercera interpretación (que juzgo irrefutable) no sé si me atreveré a añadir una cuarta, que condice muy bien con la casi divina modestia de Pierre Menard: su hábito resignado o irónico de propagar ideas que eran el estricto reverso de las preferidas por él. (Rememoremos otra vez su diatriba contra Paul Valéry en la efimera hoja superrealista de Jacques Reboul.) El texto de Cervantes y el de Menard son 
verbalmente idénticos, pero el segundo es casi infinitamente más rico. (Más ambiguo, dirán sus detractores; pero la ambigüedad es una riqueza.)

Es una revelación cotejar el Don Quijote de Menard con el de Cervantes. Éste, por ejemplo, escribió (Don Quijote, primera parte, noveno capítulo):

...la verdad, cuya madre es la historia, émula del tiempo, depósito de las acciones, testigo de lo pasado, ejemplo y aviso de lo presente, advertencia de lo por venir.

Redactada en el siglo diecisiete, redactada por el "ingenio lego" Cervantes, esa enumeración es un mero elogio retórico de la historia. Menard, en cambio, escribe:

...la verdad, cuya madre es la historia, émula del tiempo, depósito de las acciones, testigo de lo pasado, ejemplo y aviso de lo presente, advertencia de lo por venir.

La historia, madre de la verdad; la idea es asombrosa. Menard, contemporáneo de William James, no define la historia como una indagación de la realidad sino como su origen. La verdad histórica, para él, no es lo que sucedió; es lo que juzgamos que sucedió. Las cláusulas finales-ejemplo $y$ aviso de lo presente, advertencia de lo por venir-son descaradamente pragmáticas.

También es vívido el contraste de los estilos. El estilo arcaizante de Menard -extranjero al fin-adolece de alguna afectación. No así el del precursor, que maneja con desenfado el español corriente de su época.

No hay ejercicio intelectual que no sea finalmente inútil. Una doctrina es al principio una descripción verosímil del universo; giran los años y es un mero capítulo -cuando no un párrafo o un nombre-de la historia de la filosofía. En la literatura, esa caducidad es aún más notoria. El Quijote-me dijo Menard - fue ante todo un libro agradable; ahora es una ocasión de brindis patriótico, de soberbia gramatical, de obscenas ediciones de lujo. La gloria es una incomprensión y quizá la peor.

Nada tienen de nuevo esas comprobaciones nihilistas; lo singular es la decisión que de ellas derivó Pierre Menard. Resolvió adelantarse a la vanidad que aguarda todas las fatigas del hombre; acometió una empresa complejísima y de antemano fútil. Dedicó sus escrúpulos y vigilias a repetir en un idioma ajeno un libro preexistente. Multiplicó los borradores; corrigió tenazmente y desgarró miles de páginas manuscritas. No permitió que fueran 
examinadas por nadie y cuidó que no le sobrevivieran. En vano he procurado reconstruirlas.

He reflexionado que es lícito ver en el Quijote "final" una especie de palimpsesto, en el que deben traslucirse los rastros -tenues pero no indescifrables - de la "previa" escritura de nuestro amigo. Desgraciadamente, sólo un segundo Pierre Menard, invirtiendo el trabajo del anterior, podría exhumar y resucitar esas Troyas...

"Pensar, analizar, inventar (me escribió también) no son actos anómalos, son la normal respiración de la inteligencia. Glorificar el ocasional cumplimiento de esa función, atesorar antiguos y ajenos pensamientos, recordar con incrédulo estupor que el doctor universalis pensó, es confesar nuestra languidez o nuestra barbarie. Todo hombre debe ser capaz de todas las ideas y entiendo que en el porvenir lo será".

Menard (acaso sin quererlo) ha enriquecido mediante una técnica nueva el arte detenido y rudimentario de la lectura: la técnica del anacronismo deliberado y de las atribuciones erróneas. Esa técnica de aplicación infinita nos insta a recorrer la Odisea como si fuera posterior a la Eneida y el libro Le jardin du Centaure de madame Henri Bachelier como si fuera de madame Henri Bachelier. Esa técnica puebla de aventura los libros más calmosos. Atribuir a Louis Ferdinand Céline o a James Joyce la Imitación de Cristo ¿no es una suficiente renovación de esos tenues avisos espirituales? 


\section{BIBLIOGRAFÍA}

Abud, Eduardo. "Congruencia e interpretación en El curioso impertinente". Divergencias $3, \mathrm{~N}^{\circ} 1,2005$, pp. 1-11.

Anónimo (¿Alejo Carpentier?). “Al lector”. Del donoso y grande escrutinio del cervantismo en Cuba. Edición a cargo de José Antonio Baujín, Haydée Arango, Julián Ramils y Leonardo Sarría, La Habana, Academia Cubana de la Lengua, 2005, pp. XLI-XLV.

Arciniegas, Germán. "Don Quijote y la Conquista de América”. Revista Hispánica Moderna 1, $\mathrm{N}^{\circ} 4,1965$, pp. 11-16.

Bardon, Maurice. “Don Quichotte” en France au XVIIe et au XVIIIe siècles. París, Champion, 1931.

Barthes, Roland. Euvres complètes. París, Seuil, 2002.

BAuJín, José Antonio. "De la cabalgata cervantina por los caminos de la cultura cubana". Del donoso y grande escrutinio del cervantismo en Cuba. Edición a cargo de José Antonio Baujín, Haydée Arango, Julián Ramils y Leonardo Sarría, La Habana Academia Cubana de la Lengua, 2005 pp. XIX-XXXIX.

Berman, Antonie. "La traduction des oeuvres latino-américaines en France". Multilingua 4, $\mathrm{N}^{\circ} 1,1985$, pp. 208-209.

Blanchard, Marc. "Site unseen. Cuba in the Rue Jacob". Sites 5, N¹, 2001, pp. 79-88.

Buci-Glucksmann, Christine. "L'oeil baroque de la cámera”. Raoul Ruiz. París, Dis Voir, 1987, pp. 9-41.

Canavaggio, Jean. Don Quichotte, du livre au mythe. París, Fayard, 2005.

Cabrera Infante, Guillermo. "Discurso Guillermo Cabrera Infante, Premio

Cervantes 1997”. Rtve (web), 20 de octubre de 2014, consultado el 21 de noviembre de 2021, disponible en: https://www.rtve.es/rtve/20141020/discurso-guillermo-cabrera-infantepremio-cervantes-1997/1033044.shtml .

Obras completas. Barcelona, Galaxia Gutenberg, 2010.

De Cervantes, Miguel. Don Quijote de la Mancha. Madrid, Real Academia Española, 2004.

CASTRo, Fidel. Nada podrá detener la marcha de la historia. (Entrevista con Jeffrey Elliott y Mevyn Dymally). La Habana, Editora Política, 1985.

Carpentier, Alejo. "Un nuevo Retablo del Maese Pedro". Del donoso y grande escrutinio del cervantismo en Cuba. Edición a cargo de José Antonio Baujín, Haydée Arango, Julián Ramils y Leonardo Sarría, La Habana, Academia Cubana de la Lengua, 2005, pp. 553-556.

Obras completas. Tomo VIII. Ciudad de México, Siglo XXI, 1985.

Chartier, Roger. Cardenio entre Cervantès et Shakespeare. Histoire d'une pièce perdue. París, Gallimard, 2011.

"La Europa castellana durante el tiempo de El Quijote". España en Tiempos del Quijote. Antonio Feros Carrasco y Juan E. Gelabert (coord.), Barcelona, Taurus, Madrid, 2004, pp. 129-158.

Cioranescu, AleXandre. Le Masque et le visage. Du baroque espagnol au classicisme français. Ginebra, Droz, 1983. 
Compagnon, Antoine. “Pourquoi 1966?”. LHT 11, 2013.

Couderc, Cristophe. "Don Quichotte et Sanche sur la scène française (xviie et xviiie siècles)". Mélanges de la Casa de Velasquez 37, N², 2007, pp. 33-49.

CozArinsky, Edgardo. "Sarduy, prisionero de Saint-Germain-des-Prés". El pase del testigo. Buenos Aires, Sudamericana, 2001, pp. 121-132.

CuiÑas, Macarena. "Cervantes y don Quijote en el universo poético lezamiano". En Anales Cervantinos XXXVII, 2005, pp. 297-311.

Deleuze, Gilles. Le pli. Leibniz et le baroque. París, Minuit, 1988.

Díaz, Valentín. "Roland Barthes y Severo Sarduy". Actas del VII Congreso Internacional Orbis Tertius de Teoría y Crítica Literaria realizado durante los días 18, 19 y 20 de mayo de 2009, en La Plata. Disponible en: http://www.memoria.fahce.unlp.edu.ar/trab_eventos/ ev.3536/ev.3536.pdf

"Severo Sarduy y Jacques Lacan: du côté du Baroque". ALEA 18, º2, 2016, pp. 243-265.

Dobry, Edgardo. "Barroco y modernidad: De Maravall a Lezama Lima”. Orbis Tertius 14, $\mathrm{N}^{\circ} 15,2009,(\mathrm{~s} / \mathrm{p})$.

Domínguez, José. "Don Quijote y Sancho en Cuba: Pablo de la Torriente, caballero de sueños revolucionarios”. Islas 47, N¹45, 2005, pp. 99-108.

Fernández Retamar, Roberto. “Calibán”. Todo Calibán. Buenos Aires, ClaCSO, pp. 19-81.

Filer, Malva. "Salvador Elizondo and Severo Sarduy; Two Borgesian Writers". Borges and His Succesors. The Borgesian Impact on Literature and the Arts. Edna Aizenberg (ed.). Columbia, University of Missouri Press, 1990, pp. 214-226.

Foucault, Michel. "Histoire de la folie à l'âge classique". Euvres. I., Gallimard, París, 2015. "La littérature et la folie". En Folie, langage, littérature. París, Vrin, 2019, pp.

89-109.

"Le langage de la folie". En La grande étrangère. À propos de littérature. París, EHESS, 2013, pp. 21-70.

"Les mots et les choses". En Euvres. I., París, Gallimard, 2015.

"Don Quichotte par Michel Foucault", emisión radial realizada en 1961, disponible en: https://www.youtube.com/watch? $\mathrm{v}=$ aolyT1TuOzA\&t=21s

Flaubert, Gustave. Correspondance. Nizet, Verona, 2001.

Gallo, Rubén. "Sarduy avec Lacan: The Portrayal of French Psychoanalysis in Cobra and La simulación”. Revista Hispánica Moderna 60, Nº1, 2007, pp. 34-60.

"Severo Sarduy, Jacques Lacan y el psicoanálisis. Entrevista con François Wahl”. Revista Hispánica Moderna 59, №1/2, 2006, pp. 51-59.

Gamerro, Carlos. Borges y los clásicos. Buenos Aires, Eterna Cadencia, 2016.

Ficciones barrocas. Una lectura de Borges, Bioy Casares, Silvina Ocampo, Cortázar, Onetti y Felisberto Hernández. Buenos Aires, Eterna Cadencia, 2011. 
GonZÁLez, OnEYdA. "François Wahl conversa sobre Severo Sarduy: radicalmente no-realista". Rialta (web), 25 de enero de 2021, consultado el 21 de noviembre de 2021, disponible en: https://rialta.org/francois-wahl-conversa-sobre-severo-sarduy-radicalmente-no-realista/

GonzÁlez Echeverría, Roberto. "Carta de Severo". Conferencia inaugural del IV Coloquio Literatura y Margen, dictada el día 27 octubre de 2016 en la Sede de la Rectoría de la Universidad Nacional de Tres de Febrero (UTREF), en Buenos Aires. Disponible en: https://rialta.org/carta-de-severo/

Goulemot, Jean Marie, Lydia Vásquez y Juan Manuel Ieas. "La locura en el siglo de la razón: Visiones de Don Quijote en el siglo XVIII francés". Don Quijote en los cinco continentes. Acerca de la recepción internacional de la novela cervantina. Hans Christian Agendorn (coord.), Cuenca, Ediciones de la Universidad de Castilla-La Mancha, 2016, pp. 261-292.

Guerrero Gustavo. "Algunas notas sobre Sarduy y su neobarroco". América: Cahiers du CRICCAL 20, 1998, pp. 89-98.

Guevara, Ernesto. Epistolario de un tiempo. Cartas 1947-1967. María del Carmen Ariet García y Disamis Arcia Muñoz (comp.), Bogotá: Ocean Sur, 2019.

Hegel, G. W. F. Lecciones sobre la estética. Madrid, Akal, 1989.

Hidalgo, Max. "Usos críticos de Borges en el campo intelectual francés (de Blanchot a Foucault)". Una profunda necesidad en la ficción contemporánea: la recepción de Borges en la república mundial de las letras. Brigitte Adriaensen, Meike Botterweg, Maarten Steenmeijer y Lies Wijnterp (eds.), Madrid, Iberoamericana, 2015, pp. 89-109.

Hugo, Víctor. Oeuvres. Critique. París, Roger Lafont, 1991.

Iriarte, Ignacio, "El Barroco anacrónico de Severo Sarduy”. En Recial n9 (14), 2018.

Jill Levine, Susanne. "Cobra/Borges. Es baroc(o) (exe)gesis. Un estudio de la intertextualidad". Severo Sarduy. VV. AA., Madrid, Fundamentos, 1976, pp. 87-105.

Jurado, Agapita. El Quijote cabalga en Europa. (Siglo XVII). Florencia, Etidrice Fiorentina, 2018.

Lacan, Jacques. “Aún”. El Seminario de Jacques Lacan. Libro 20. Aún. 1972-1973. Buenos Aires, Paidós, 1998.

Le Séminaire de Jacques Lacan. Livre XX. Encore. 1972-1973. París, Seuil, 1975.

"Situation de la psychanalyse et formation du psychanalyste en 1956".Écrits. París, Seuil, 1966, pp. 459-491.

Rambeau, Frederic. Les secondes vies du sujet: Deleuze, Foucault, Lacan. París, Hermann, 2016.

Leonard, Irving A. Books of the Brave: Being an Account of Books and of Men in the Spanish Conquest and Settlement of the Sixteenth-Century New World. Cambridge, Harvard University Press, 1949.

Lezama Lima, José. "La dignidad de la poesía". El reino de la imagen. Caracas, Ayacucho, 1981, pp. 294-312.

Paradiso. Madrid, Archivos, 1988.

Leyva GonzÁlez, David. “Miguel de Cervantes y José Martí”. Revista de la Universidad 280, 2015, pp. 31-38. 
Loeza, Alejandro. "Del idealismo al carnaval: el Quijote en Cuba". Comentarios a Cervantes: Actas selectas del VIII Congreso Internacional de la Asociación de Cervantistas, Oviedo, 11-15 de junio de 2012 / Emilio Martínez Mata y María Fernández Ferreiro (coord.), Oviedo, Fundación María Cristina Masaveu Peterson, 2014, pp. 702-713.

Martí, José. Obras Completas. La Habana, Editorial de Ciencias Sociales, 1975.

Marx, Karl. El Capital. Libro Primero. Volumen I. El proceso de producción del capital. Madrid, Siglo XXI, Madrid, 2010.

La ideología alemana. Madrid, Akal, 2014.

Molloy, Sylvia. La Diffusion de la littérature hispano-américaine en France au XXe siècle. París, Presses Universitaires de France, 1971.

Montesquieu. Euvres Complètes. París, Gallimard, 1982.

Osterc, Ludovik. El pensamiento social y politico del Quijote. Interpretación históricomaterialista. Ciudad de México, UNAM, 1988.

Pauls, Alan. "Prólogo" El Cristo de la Rue Jacob y otros textos. Severo Sarduy,Santiago, Editorial Universidad Diego Portales, 2014, pp. 9-11.

Pecas de Ponsetti, Helena. Cervantes y su concepto del "arte". Estudio crítico de algunos aspectos y episodios del "Quijote”. Madrid, Gredos, 1975.

PIÑAR, Alicia. "La pintura del cartapacio en el Quijote: reflexiones desde la Historia del Arte". Cuadernos de Arte de la Universidad de Granada 50, 2019, pp. 23-38.

Piñera, Virgilio. “¿Ya leyó El Quijote?”. Lunes de Revolución 71, 8 de agosto de 1960, pp. 7-8.

Prieto, René. "In-Fringe: The Role of French Criticism in the Fiction of Nicole Brossard and Severo Sarduy". Do The Americas Have a Common Literature? Gustavo Pérez (ed.), Londres, Duke University Press, 1990, pp. 266-281.

Remos, Juan, "La tradición cervantina en Cuba”. Ensayos literarios. Madrid, Talleres Gráficos Aro, 1957.

Rivero-Potter, Alicia. Autor/lector Huidobro, Borges, Fuentes y Sarduy. Detroit, Wayne State University Press, 1987.

Robert, Marthe. L'ancien et le nouveau: de Don Quichotte à Franz Kafka. París, Grasset, 1963.

Rodríguez, Alberto. "Dos visiones cubanas de Cervantes: Enrique José Varona (1849-1933) y José de Armas y Cárdenas (1866-1919)". Cervantes e Hispanoamérica: variaciones críticas. Alberto Rodríguez, Jorge Sagastume y María Stoopen (eds.), Ciudad de México, UNAM, 2019, pp. 65-83.

Ruiz García, Claudia. "El Quijote en Francia en el siglo XVII". Horizonte cultural del Quijote. María Stoopen (comp.), Ciudad de México, UNAM, 2010, pp. 241-249.

SAde. Euvres complètes du Marquis de Sade. París, Pouvert, 1988.

SÁnchez Tallafigo, Cristina. "De la letra al símbolo: Imitaciones francesas del Quijote en el siglo XVII". Don Quijote cosmopolita. Nuevos estudios sobre la recepción internacional de la novela cervantina. Hans Christian Hagedorn (comp.), Castilla/La Mancha, Ediciones Universidad de Castilla/La Mancha, 2009, pp. 183-215.

Sarduy, Severo. "Conversation with Severo Sarduy. A dialogue". Entrevista con Dennis Seager. Dispositio 5/6, N¹5/16, 1981, pp. 129-142. 
"En persona". Entrevista con Rafael Casalina. Severo Sarduy en Cuba (1953-1961).

Cira Romero (comp.), Santiago de Cuba, Editorial Oriente, 2007, pp. 249-252. "L'écriture autonome". La quinzaine littéraire 63, 1968, pp. 3-4. "Góngora le baroque". La quinzaine littéraire 49, 1968, pp. 12-13.

"Notas a las notas a las notas... A propósito de Manuel Puig". Iberoamericana XXXVII, N76-77, 1971, pp. 555-567.

Obra completa. Compilada por Gustavo Guerrero y François Wahl. París, Galaxia Gutenberg, 2009.

Santonja Gómez-Agero, Gonzalo y María Antonia de Isabel Estrada. "El Quijote en la Cuba de Fidel Castro". La Colmena 73, 2012, pp. 15-20.

Scaramuzza, Marirosa, "Los fantasmas del Quijote. Michel Foucault, Marthe Robert, René Girard, Louis Combet”. Mélanges de la Casa de Velasquez 37, №2, 2007, pp. 123-139.

Stendhal. Euvres Intimes. II. París, Gallimard, 1982.

Sollers, Philippe. "Cervantes ou la liberté redoublée". En Théorie des Exceptions. París, Gallimard, 1986, pp. 24-33. "La boca obra". Tel Quel 4, 1970, p. 35. "Sollers dos”. En Severo Sarduy. VV. AA., Madrid, Fundamentos, 1976, p. 122.

Van Beysterveldt, Antony. "El tema de El curioso impertinente y su relación con el Quijote". Dicenda 143, N4, 1985, pp. 143-147.

Villegas, Jean-Claude. Paris, capitale littéraire de l'Amérique latine. Dijon, Éditions universitaires de Dijon, 2007.

Wahl, François. "Severo de la Rue Jacob". Obras. II. Severo Sarduy, 2011, pp. 1447-1547

Wardropper, Bruce. "The Pertinence of El curioso impertinente". PMLA 72, №4, 1957, pp. 587-600. 